\title{
パーシャルデンチャー・デザインが鉤霜の挙動におよぼす影響
}

九州歯科大学䨑科補経学第 1 講座 (指導: 豊田静夫教授)

森山茂美

平成元年 9 月 28 日受付

\section{Effects of Partial Denture Clasp Assembly on Abutment Tooth Movement}

\section{Shigemi Moriyama}

First Department of Prosthetic Dentistry (Director : Prof. Shizuo Toyoda)

Kyushu Dental College, Kitakyushu, Japan

In order to minimize the damage to the periodontal tissues of the abutment tooth, numerous studies on the abutment tooth behavior with partial prostheses have been undertaken in various ways using strain gauge, photoelastic and finite element methods. However, it was difficult by these methods to detect the three-dimensional dynamic movement of the abutment tooth.

The present study examined three-diminsionally the effects of the partial denture clasp assembly and its component parts on the abutment tooth movement utilizing the mandibular kinesiograph (MKG).

The mandibular distal-extension removable partial denture was constructed on a simulation model of Kennedy Class $\mathbb{I}$ Modification 1 . The gingival and alveolar ridge areas and the roots of the abutment teeth were covered with silicone material for simulating the resilient natural mucosa and membrane. Starting from the original denture consisting of denture bases on both sides of the arch and five retainers connected by a lingual plate, the experimental design was altered by reducing the components one after another.

The lateral loading to the tooth on the denture caused significantly larger movement of the abutment tooth than the vertical loading. Especially, the inclination of the abutment tooth in the distal direction, which might be the principal factor causing damages to the tooth, was induced by the mesial or buccal loading to the denture tooth. It was also found that the tooth movement was smaller when the load was applied to the second molar of the denture than to the second premolar.

The original design of the denture showed the smallest tooth movement in general. There was a tendency that the tooth movement became easy to occur by a smaller load as the components were reduced one after another. However, the design leaving the indirect retainers on the first premolar of the other side of the arch connected by a lingual bar showed smaller tooth movement in the distal direction rather than the original denture. In the unilateral denture with the indirect retainers being removed, 
on the other hand, extremely larger tooth movement was found to occur.

Further reduction in the basal area of the denture base made the denture more unstable, resulting in significantly increased tooth movement.

When the applied load was removed, the abutment tooth returned to its original position taking a different route from its inclination pass, occasionally rotating.

\section{Key words : Abutment tooth $/ R P D$ components $/ M K G /$ Simulation model}

\section{緒言}

可撤性遊離端義歯に加わった咬合力は床下組織および 鈎歯に伝達されるが，しばしば咬合力による鈎歯の挙動 が生理的許容範囲を越えて鈎茵の損傷を来すために，従 来からパーシャル・デンチャ一の設計原則としててれら 咬合荷重に対するストレスを最小限にして鈎藏の保護を 図ることに主眼が置かれてきた。

てれまでに考えられてきた遊離端義歯デザインの根本 原則には，顎堤に加わる咬合力を減少させるために人工 歯咬合面在縮小する方法 ${ }^{1,21}$ ，人工㐘咬合面に加わった 力石可及的に広範囲に分散させ，単位面積当たりの咬合 力を軽減するために床面積を拡張したり，多くの歯に維 持装置を設定して多数歯に咬合力を分散，伝達する方法 3-10)，などがある。さらに歯なら び歯周勒帯の解剖学 的な形態が垂直力に比して側方的な力による歯の抵抗力 が著しく弱いととから側方的率引力を減少させるために

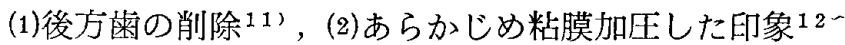
14，（3)ストレス・ブレーカー装置の使用15-21)などの 方法が用いられてきた。

Steffel は100以上の文献から 3 つの応力配分の型式 に分類している22,23)．すなわち，ストレス・ブレ一カ 一を用いることによって床下組織に選択的に荷重を分散 する方法，床下組織を加圧印象することによって歯と顎 堤間の変位量差を均等化する方法, そして床下組織の負 担過重を防ぐために荷重を広範囲の歯に配分する方法で ある。

現在では, フレキシブルな装置を用いて鈎柬と義歯床 を連結する方法に対しては，否定的な見方が補綴学界の 趨勢を占めているように見受けられるが，広範囲に咬合 力を分散させて銁歯を保護しようとする考え方をはじめ 他の方法については依然として変わりない支持を得てお り，その際の鈎歯の挙動については多くの報告がなされ てはいる、しかし，個々のデザインを設定する場合の明 確な判断の基準がなく，総義歯に比べてパーシャル・デ ンチャ一の理論的な設計基準が遅れている一因となって
いる．乙の問題を解決するためには代表的な各種デザイ ンの 3 次元的，かつ動的な鈎歯の挙動を知るととが不可 久であろうと考える、䨑に広範囲に咬合力を配分する場 合，片側遊離端症例においては義歯の主維持装置，副維 持装置，床の大きさ，ならびに連結装置の形態，数，位 置，堅军さ等が鉤歯の挙動に影響すると考えられる．そ こで構成要素が鈎歯の挙動にどのように影響するかを調 ベるために，シミュレーション・モデルにより，類運動 分析装置 (MKG) を用いて検討した結果，徒来の方法 24ー37)では見い出し得なかった幾つかの知見を得たので 報告する．

\section{実 験 方 法}

\section{I ．計測装置の記録精度}

義菌に負荷がかかった時の鉤菌の変位方向および変位 量の計測ならびに記録には MKG（K６ダイアグノステ イックシステム EX，マイオトロニクス社製）を用い た、まずセンサー・アレー改良型であるてのシステムの 記録再現精度について調べた。乙の装置のマグネット $1 \mathrm{~mm}$ 問隔の移動に対してディスプレー上ではどのよう に表示されるかを検討したが，その移動量の設定にはデ ジタル式 3 次元読取り顕微鏡を用いて行った。

\section{II . 実駼装置}

A.シそュレーション・モデル

本研究の分析用模型には，臨林的に最も頻繁に遭遇 し，かつ補緅処置上さまざまな問題点がある遊離端義菌 症例として，右側第 2 小臼歯，第 $1 ， 2$ 大臼歯ならびに 左側第 2 小田霜および第 1 大曰歯欠損のケネディーII 級 1 類を用いた (Fig. 1).

全ての残存歯ならびに顎堤には，天然組織と類似した 可動性を与えるために，シリコーン・ラバー(イグザフ レックス，GC社およびネオシュナガー，ネオ社）でそ れぞれ苗根表面および罘堤表面を被覆した。偽似菌根膜 および偽似顎堤粘膜の愿さについては，歯槽窩側壁で $0.5 \mathrm{~mm}$, 根尖部で $0.7 \mathrm{~mm}$, 顎堤粘膜は $1.2 \mathrm{~mm}$ の厚さ に調整した。 


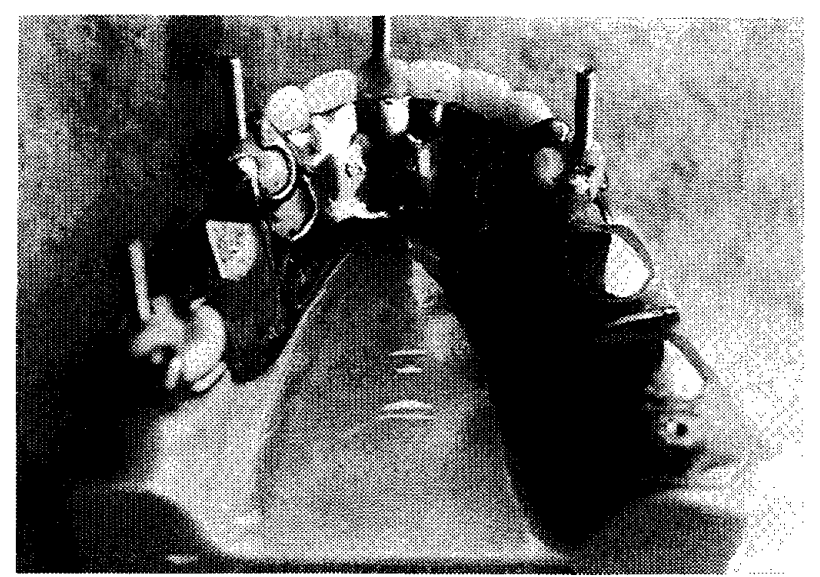

Fig. 1 Simulation model of Kennedy Class II Modification 1 and original design of denture.

なお，本研究では隣在歯に制約を受けない自由な鈎蒾 の挙動を観察するのが目的であったので, $\overline{3 \mid}$ と $\overline{4 \mid}$ 間 のコンタクト・ポイントは削除して銁雬 $\overline{4}$ が近心方向 へも傾斜，変位することができるようにした。

B . 義霜のデザインと荷重点

オリジナルなデザインの義茵から, 直接維持装置を除 く他の維持装置, 連結装置, 義囦床の形態を順次削除, 変更した場合の鈎蒾の举動の相対的変化を観察すること が目的であり，各種デザィンの変更は次の順序で行っ た。

1) 最初にデザィンされた義歯(デザィン I )

(Fig. 2).

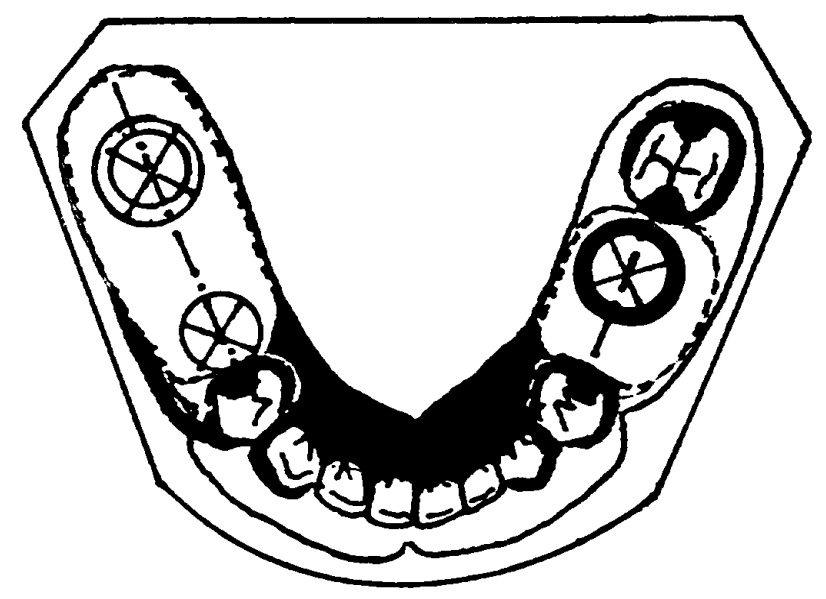

Fig. 2 Original design of the experimental distal-extension denture.

2）左側第 2 大臼雬のリング鉤々先ならびに遠心レスト の除去（デザイン II）

3）近心レストを除く同リング鉤々腕全ての除去（デザ

\section{イン III)}

4) 近心レストを含め同リング鈎全ての除去（デザイン IV)

5 ）左側犬歯のエーカース鉤の除去（デザィンV）

6) 右側犬歯のエーカース鈎の除去（デザィンV）

7) リンガルプレートからリンガルバーへの形態修正 (デザィン VII)

8 ）左側第 1 小臼歯のエーカース鉤およびリンガルバー の除去（デザイン VIII）

9 ）右側義歯床の縮小（デザイン $\mathbb{X}$ )

なお，右側第 2 小曰歯および第 2 大田霜ならびに左側 第 1 大曰霜相当部にピラミッド状の金属製 4 角錐の台を 設置し, その頂点, 舌側, 近心, 煩側, および遠心面に それぞれの面に対して垂直的に $1 ， 3 ， 5 \mathrm{~kg}$ の荷重を 加え，そのときの鉤崡爾冠の挙動を観察した (Fig. 3).

\section{C . 鉤画の拡大挙動観察装置}

鉤藏 $\overline{4 \mid}$ の挙動を拡大して観察するために歯冠部にエ クステンションアームを歯軸と平行に固定し，そのアー ム先端に取り付けた MKG マグネットの動きを記録し た (Fig. 4). 柬の回転中心を苗根尖側 $1 / 3$ とした場合， その回転中心からアーム固定部までが $8 \mathrm{~mm}$ であったの で, 鉤㐘の変位量を30倍に拡大できるようにアームの長 さを $232 \mathrm{~mm}$ とした，磁力線の影響を避けるためアーム には木製の棒を用いた．なお， MKG マグネットはエク ステンションアームの先端に, 床面と平行にかつ模型正 中線と直交するように設定した。 さらに MKG ディス プレーならびにレコーダー上で10倍まで拡大できるため に, 実際の動きは本実験装置では最大 300 倍まで拡大し て観察できたととになる。

\section{実 験 結 果}

\section{I 、計测装置の記録精度}

Fig. 5 は，原点から $x$ 方向 (近，遠心方向)，y方向 (煩，舌側方向）および $z$ 方向（上下方向）に $1 \mathrm{~mm}$ 間隔 でマグネットを平行移動させた時に, MKG ディスプレ 一上に記録されたマグネット軌跡を示したものである. 矢状面，前頭面，水平面のいずれの記録においても直交 した等間隔の格子にならず, ヨコ方向が压平された形の ひずみがみられた。

II · 鈎蒾の挙動について

本実験での鉤歯の変位を示すマグネットの動きは，乙 れらひずんだ格子と重ね合わせ，Morikawa ら（1988， 1989〉38，391の方法にしたがって各軸からの相対的距離 を求めて等間隔スケールの直交座標にプロットした. 


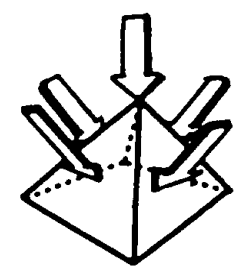

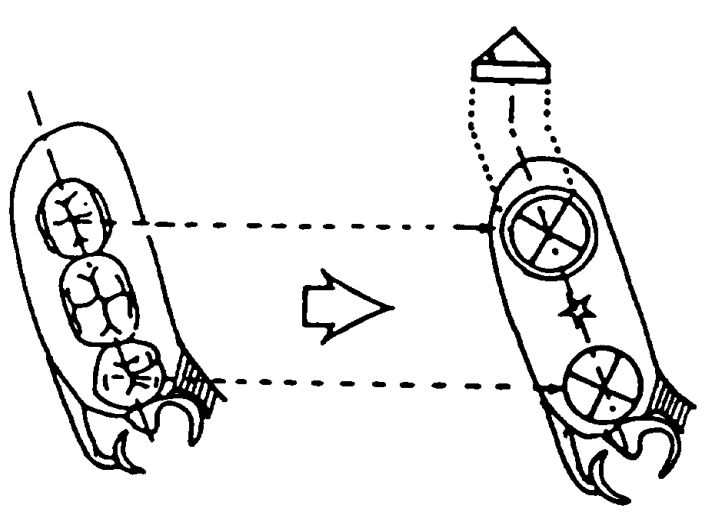

(14) is
(1)

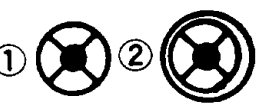

(3)

B

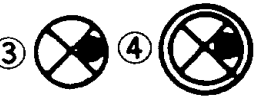

(5)

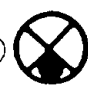

68

L

(7)

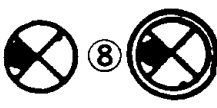

(9)

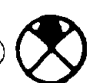

(10)

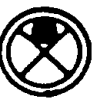

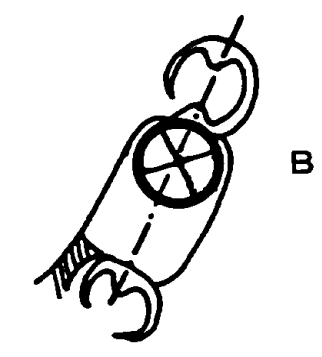

(11)

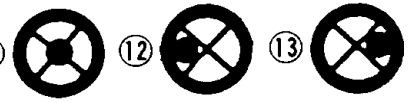

Fig. 3 Experimental Class II partial denture and loading portions on the pyramids substituting for the right second premolar and molar and left first molar. The load was perpendicularly applied on the following portions.

(1) : top of the right second premolar pyramid

(2): top of the right second molar pyramid

(3) : lingual oblique plane of the right second premolar

(4) : lingual oblique plane of the right second molar

(5) : mesial oblique plane of the right second premolar

(6) : mesial oblique plane of the right second molar

(7) : buccal oblique plane of the right second premolar

(8) : buccal oblique plane of the right second molar

(9) : distal oblique plane of the right second premolar

(10): distal oblique plane of the right second molar

(11) : top of the left first molar

(12) : lingual oblique plane of the left first molar

(13) : buccal oblique plane of the left first molar

(14): Dislodging force was applied perpendicularly to the occlusal plane.

Fig. 6 はこのようにして得られたデザイン情の場合の 例である. $+\boldsymbol{x},+\boldsymbol{y},+\boldsymbol{z}$ 方向はそれぞれ遠心, 舌 側, 上方への方向を示し， $-\boldsymbol{x},-\boldsymbol{y},-\boldsymbol{z}$ はそれぞれ 逆の方向を示す. とれらの矢状面, 前頭面ならびに水平 面上での動きから，義䨑床荷重点部に負荷した時には鉤 歯は水平面上を平行移動しているのではなく近遠心, 左 右，下方へ傾いているととがわかる。したがって，以下 の図表では水平面上での変位のみを表示しているが，い
ずれも下方への変位成分を含んでいる．図中の実線で表 した直交軸は顔面正中線ならびにそれと直交する線であ り，1 点鎖線は模型臼柬部菌槽頂線に沿った近遠心方向 ならびにそれと直交する煩舌側方向を示している。

なお，水平面上での鈎蒾の変位方向は，Fig．7亿示 すように略称する。

A . 各種デザイン, 各種荷重成分別による挙動の比較 各種デザイン，各種荷重方向別による鈎䨑の変位量な 

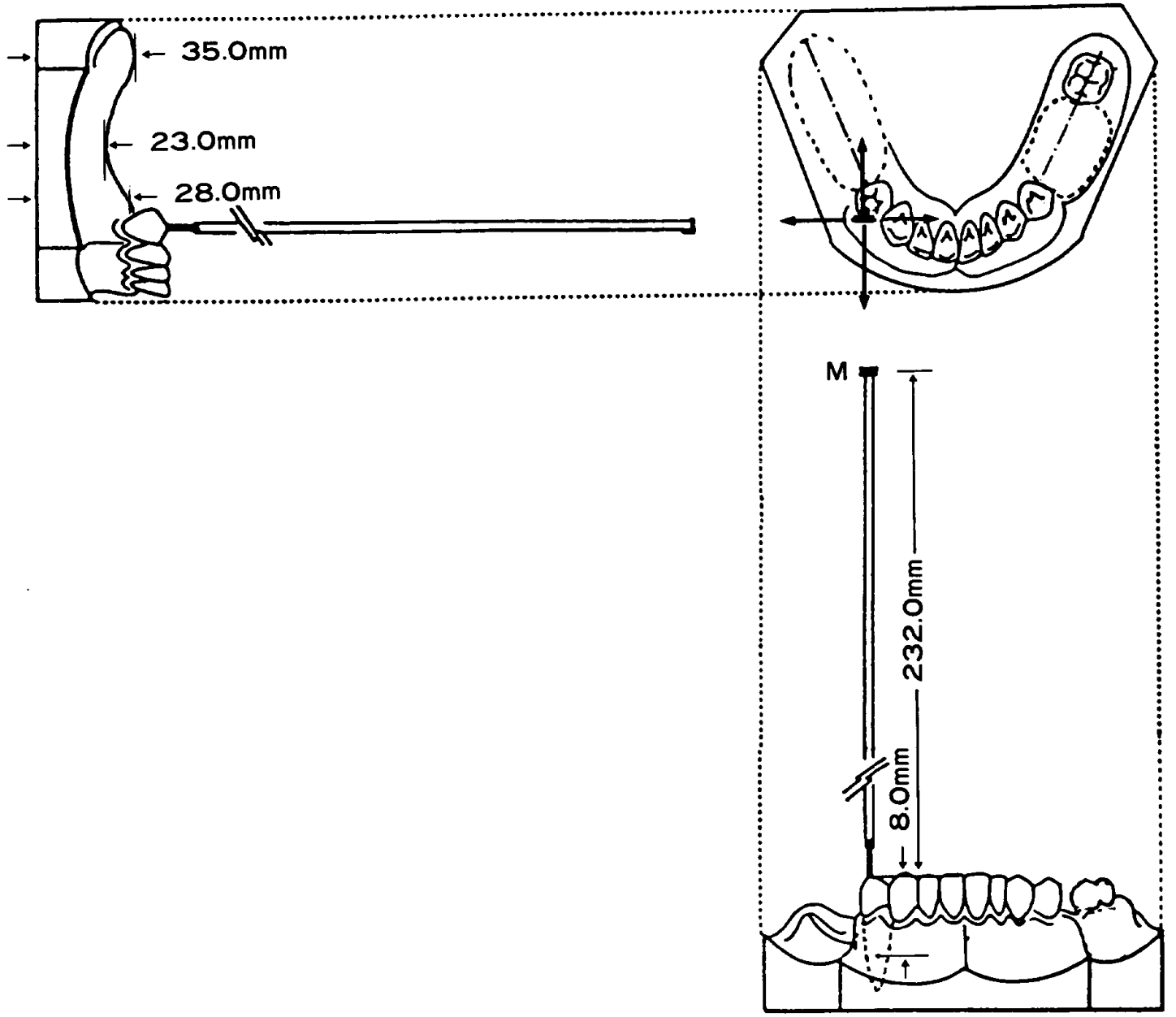

Fig. 4 Wooden rod extension arm for magnifying the tooth movement. The magnet (M) for MKG assembly was installed on the top of the arm and the arrows denote the directions of measurement.

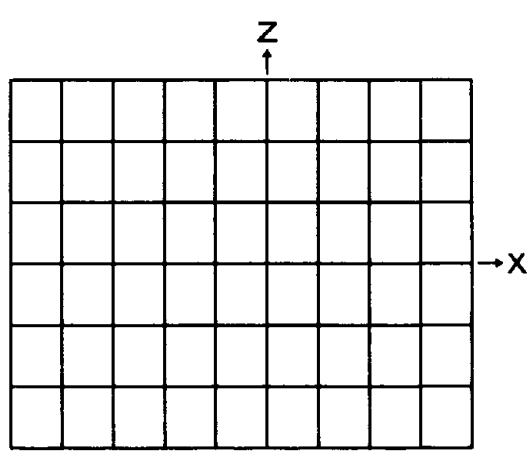

a. Sagittal plane

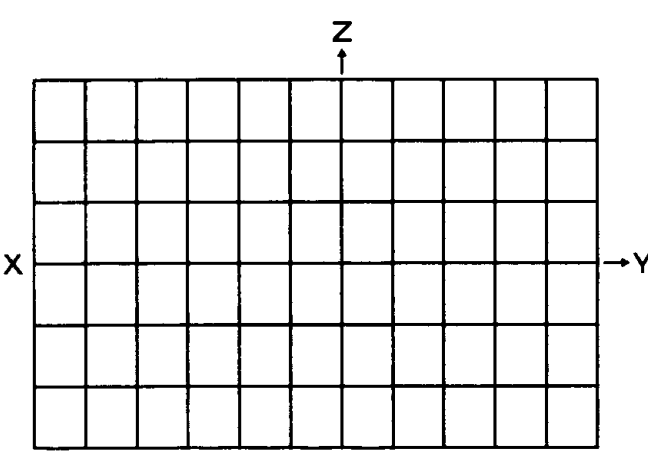

b. Frontal plane

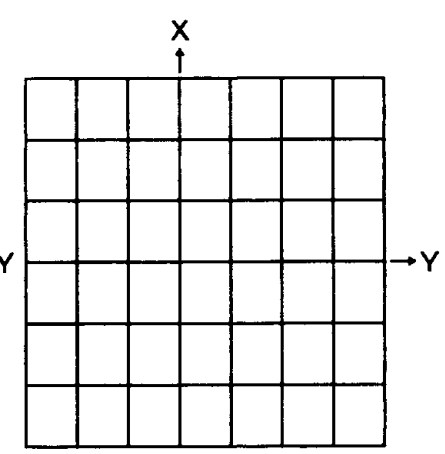

c. Horizontal plane

Fig. 5 Distorted MKG records of the magnet movement obtained by successively shifting the magnet by $1 \mathrm{~mm}$ parallel to the $\mathrm{x}^{-}, \mathrm{y}$-and $\mathrm{z}$-axes. 
vertical load

sagittal view
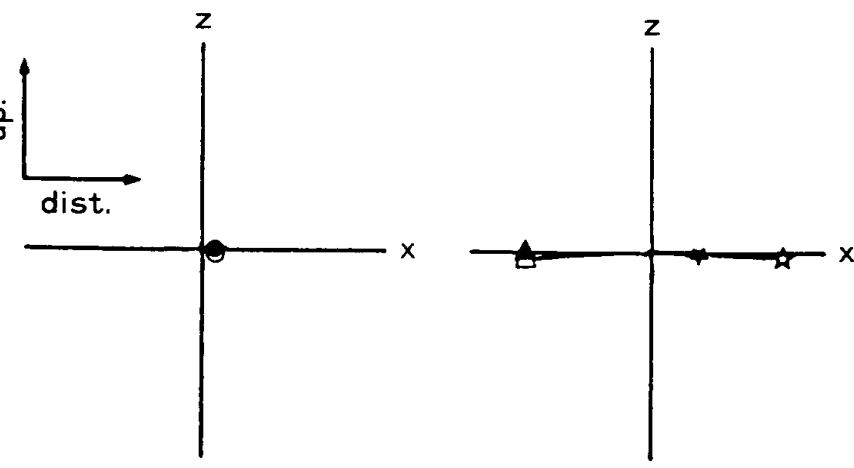

bucco-lingual

load

mesio-distal

load
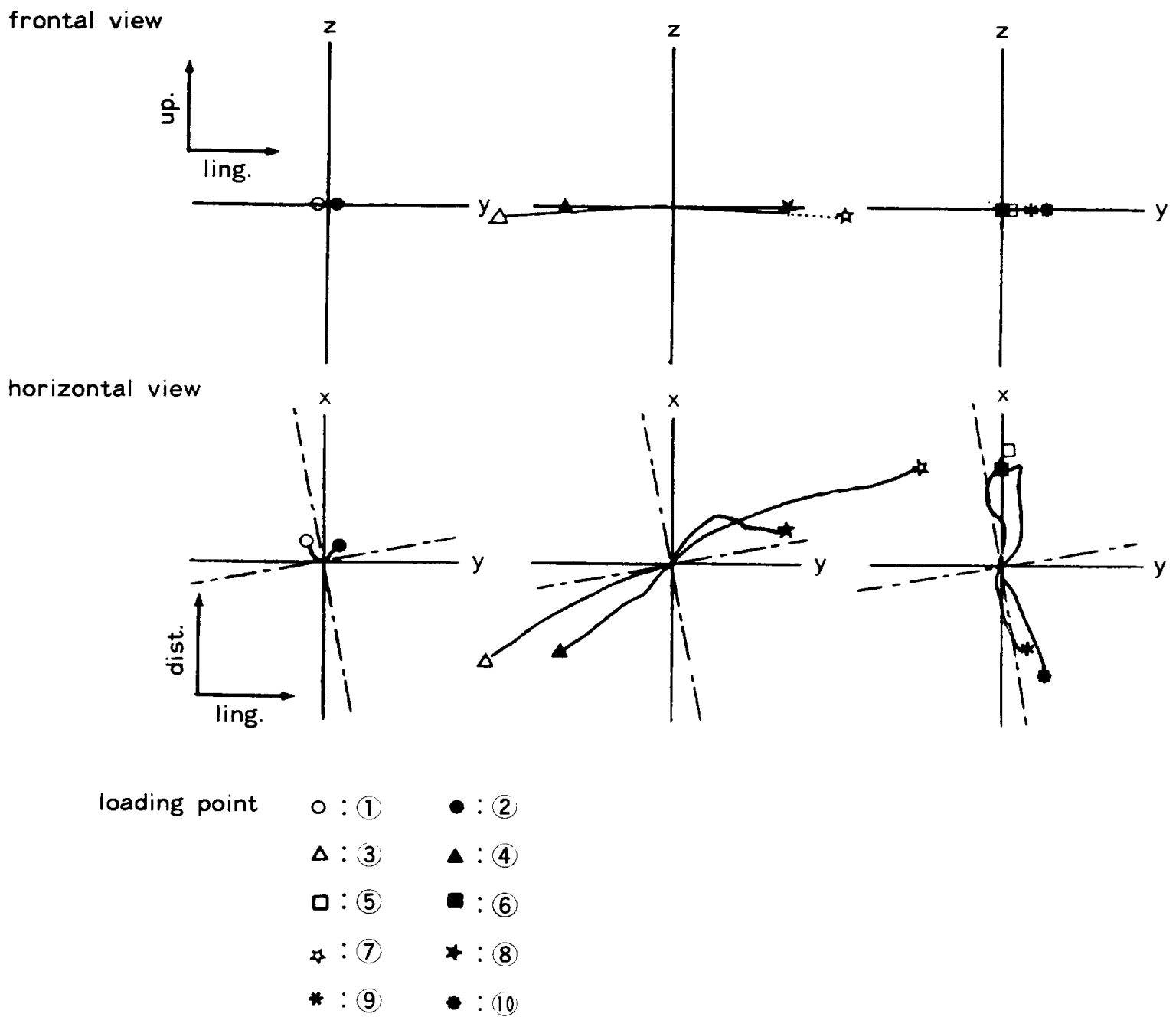

Fig. 6 MKG records of the traces of the abutment tooth movement in design VIII, on sagittal, frontal and horizontal views. The chain lines denote the alveolar ridge line and the bucco-lingual line perpendicular to the ridge. 


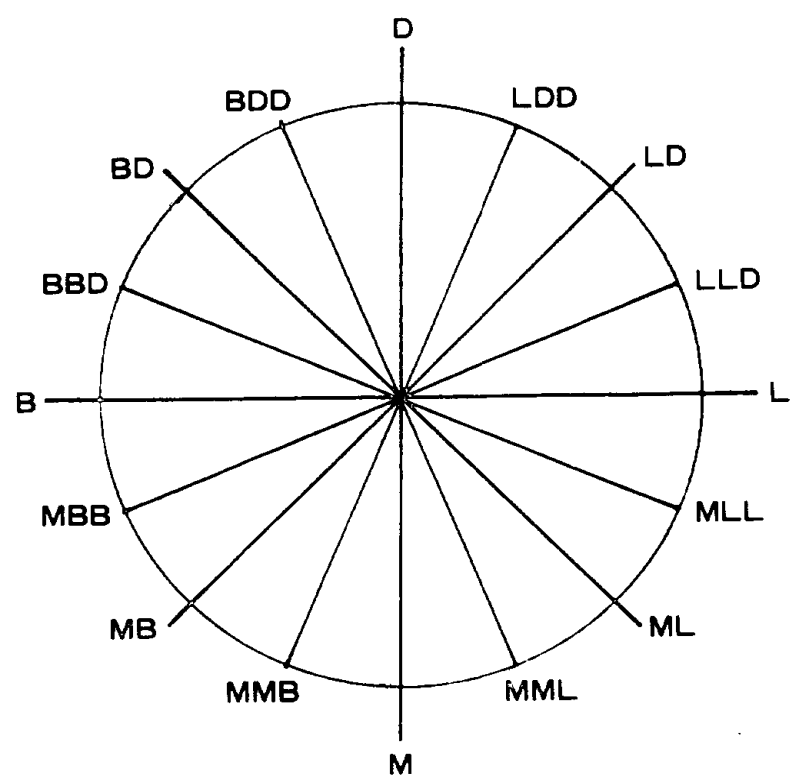

Fig. 7 Abbreviation of the moving directions of the abutment tooth under loads in horizontal plane.

M : mesial direction

B : buccal direction

$\mathrm{L}$ : lingual direction

$\mathrm{D}:$ distal direction

らびに変位方向を Fig. 8 に示す. 点線は, 各デザイン, 各荷重ごとの挙動の変位最終点を結んで, 義柬床に負荷 した場合の鈎雪の概略的な変位領域を示したものであ る、荷重方向ならびに荷重点を一定にして, その荷重量 のみを増加させた場合，詳細には進路方向は一定ではな かった。しかし総体的にみるとほとんど変位方向は変わ らず変位量のみが増大寸る傾向があった，それらをまと めたものが Table 1 である. また Fig. 8 の変位領域 の面積を計測し，Fig. 9 および Table 2 に示してい る. Fig. 10 はデザインIに対する各デザインの相対的 な変位領域の割合をあらわしている。さらに，あらゆる 荷重による変位領域の総和を近・遠心方向別に Fig. 11 に示し，デザイン I に対する総変位領域ならびに遠心方 向への変位領域の比率を Fig. 12 に表示したＦig. 9 にみられるように，5 kg 荷重時の場合，鉤㐘の変位す る領域が最も広くなり，次いで $3 \mathrm{~kg}, 1 \mathrm{~kg}$ と小さくな った。また，いずれの荷重においても概ね近心方向への 変位領域が大きかったが，デザイン四のみでは逆に遠心 方向への変位領域が大きくなった。デザイン I に対する 変位領域の比率では，近心方向ではいずれのデザイン においても荷重間に差異はほとんど認められなかった
が，遠心方向の変位領域のデザイン I に対する比率では $1 \mathrm{~kg}$ 荷重時で最も大きく，3，5 kg と小さくなった (Fig. 10)。乙れら 1，3，5 kg 荷重時の鈎歯変位領域 から重複する部分を除き, かつ近・遠心方向の変位領域 を合わせた総変位領域では，デザイン I が最も小さく，

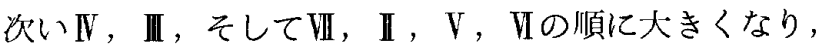
デザィン VIIでは著しく大きくなり， IXではさらに大きく 銁歯からクラスプが脱離して訃測不可能となった（Fig. 12 拈よび Table 2). しかしながら, 遠心方向への変位 量は総変位領域の傾向とは異なり, デザィン VIIがIに次 いで小さくなった（Fig.11，12 および Table 2).な お，Fig. 13 にみられるように鉤歯を遠心に毫引するの に最も関与していると考えられるのは煩側および近心か らの荷重時 $(5 \mathrm{~kg})$ においてであった．煩側ならびに 近心から負荷した場合の各デザインの鈎䨑変位量の差を 統計的に検定した結果が Table 3 である. Table 3 ならびに Table 1 から, デザインIに対して有意に小 さかったデザインは, 第 2 小曰歯相当部（以後，近心歯 と呼ぶ）に煩側から負荷した場合（荷重点(7)）のデザィ ンVI, VIならびに第 2 大曰歯相当部（以後，遠心柬と呼 ぶ）に煩側から負荷した場合（荷重点 (8)）のデザイン V，V，VIであった。また，乙の図（Fig－13）からわ かるように近心歯に垂直的に負荷した場合には，ほとん どのデザインでほぼ煩側ないしはやや遠心煩側に変位 し, 遠心函に垂直的に負荷した場合は前者と違って放散 的にあらゆる方向一変位したのちに, 最終的に近心方向 ヘターンする特徴を示した。しかしながら, 垂直的荷重 時の鉤歯変位量は, 全てのデザインにおいて極めて小さ かった.

荷重除去後の戻り経路に重点をおいて, 各デザインご との鈎柬の詳細な挙動を近心歯荷重時ならびに遠心歯荷 重時（ともに5 kg）に分けて示したものが Fig. 14 で ある.ほとんどのデザインで荷重除去後の復元経路は荷 重時の軌跡上を通らず，別の経路を通って出発点に戻っ た、しかしながら，変位量自体の大きさにかかわりなく 完全に復元し得ない場合もあった〈デザイン I 近心歯， 煩側負荷, デザイン II 近心雪, 煩側負荷およびデザィン VI 遠心荬，遠心負荷の場合など)。乙れらのデザインな らびに荷重時においては，わずかではあったがクラスプ が鉤蒾の所定の位置からずれていて復元し得ない状態が 認められ，クラスプを所定の位置に戻すことにより銁歯 も変位前の状態に戻った。

煩・舌側ならびに近心から負荷した場合は，デザイ ンの違いにより変位量には差異はあったが, 近心煩側 

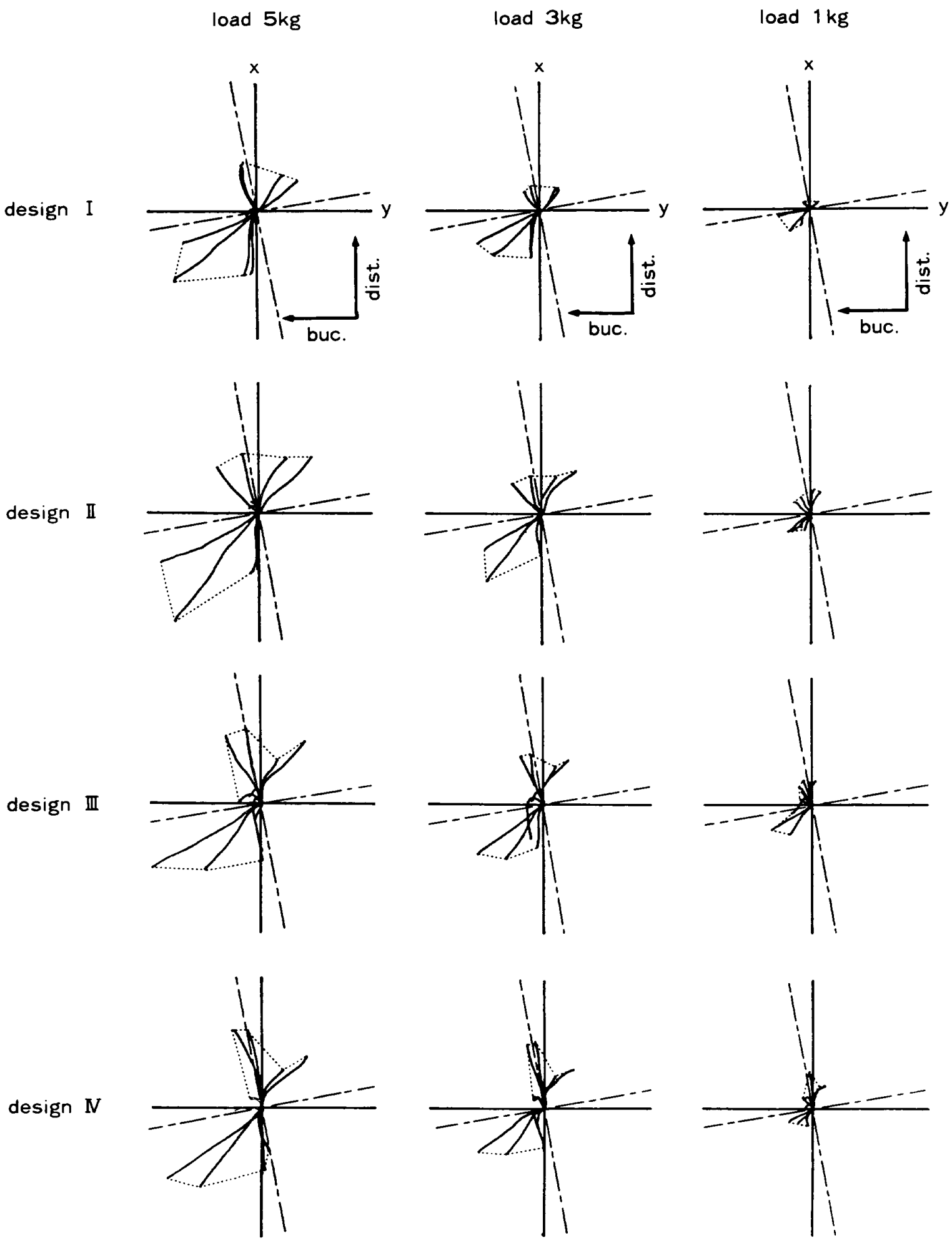

Fig. 8-1 Abutment tooth movements and maximum areas surrounded by the traces under various loads (horizontal view). 

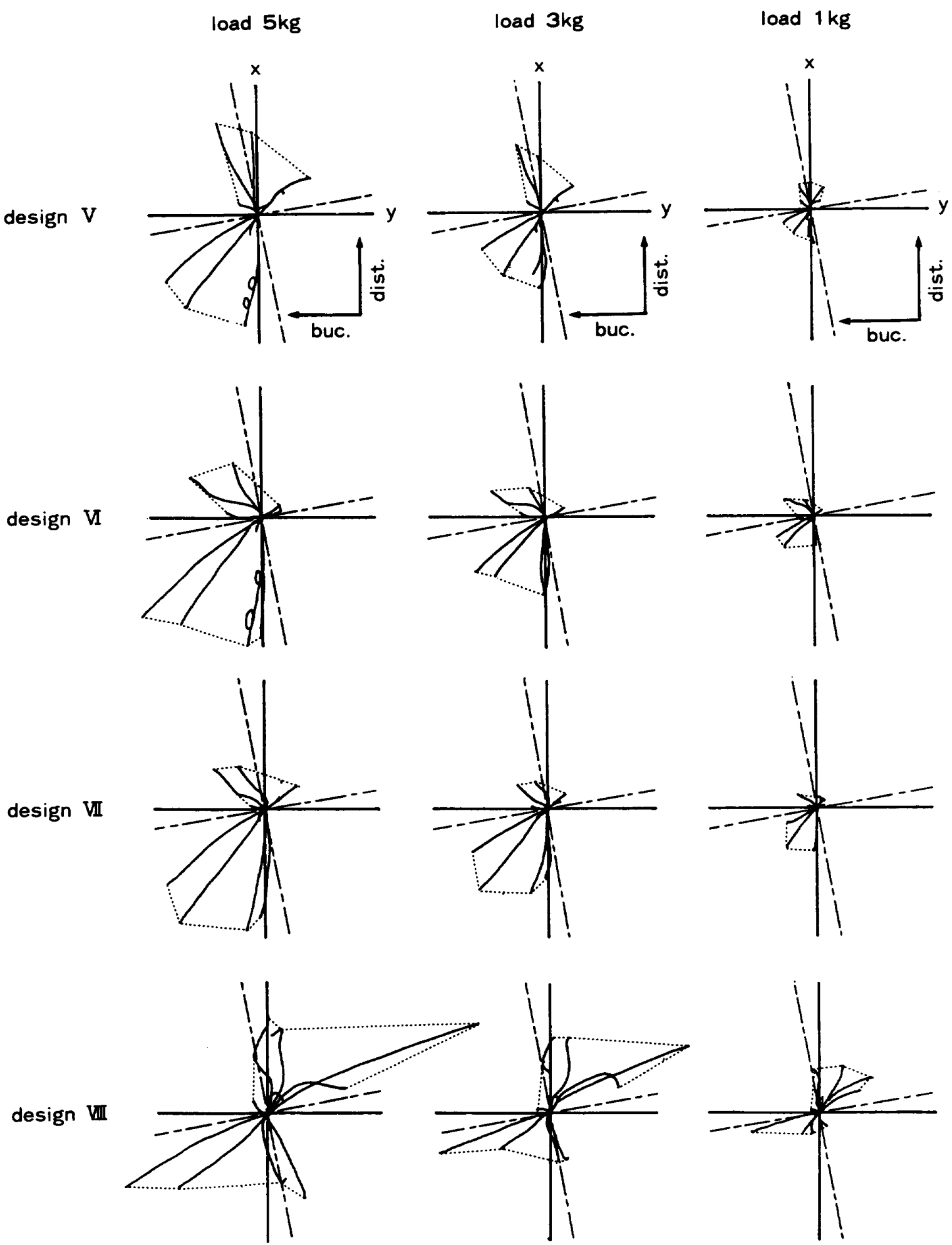

Fig. 8-2 Abutment tooth movements and maximum areas surrounded by the traces under various loads (horizontal view). 


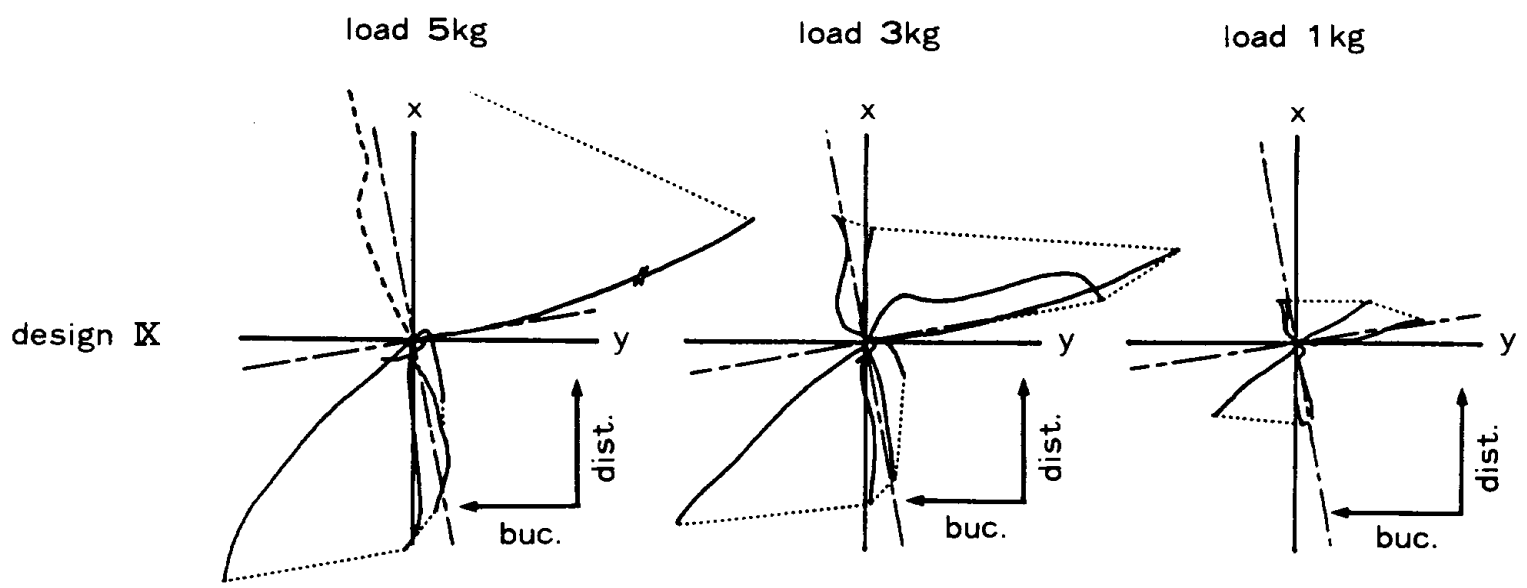

Fig. 8-3 Abutment tooth movements and maximum areas surrounded by the traces under various loads (horizontal view).

Table 1-1 Magnitude $(\mu \mathrm{m})$ and direction of the abutment tooth movement

\begin{tabular}{|c|c|c|c|c|c|c|}
\hline \multirow{2}{*}{\multicolumn{2}{|c|}{ Design Load $(\mathrm{kg})$}} & \multicolumn{5}{|c|}{ Loading point } \\
\hline & & \multirow{2}{*}{$\frac{(1)}{7.3 \mathrm{MB}}$} & \multirow{2}{*}{$\frac{\text { (3) }}{30.2 \mathrm{~B}}$} & (5) & (7) & \multirow[b]{2}{*}{$17.4 \mathrm{MMB}$} \\
\hline Des. I & 1 & & & $10.6 \mathrm{~B} \mathrm{D}$ & $9.7 \mathrm{LD}$ & \\
\hline & 3 & $9.3 \mathrm{MMB}$ & $64.1 \mathrm{MB} \mathrm{B}$ & 23.0 B D & $28.0 \mathrm{~L} \mathrm{D}$ & $45.0 \mathrm{MM} \mathrm{B}$ \\
\hline & 5 & $10.0 \mathrm{MMB}$ & 73.7 MB B & 42.2 B D D & $46.0 \mathrm{LD}$ & $60.8 \mathrm{MMB}$ \\
\hline \multirow[t]{3}{*}{ Des. $\mathbb{I}$} & 1 & 7.9 B D & $29.0 \mathrm{MB}$ & $20.6 \mathrm{~B} \mathrm{D}$ & $23.9 \mathrm{~L} \mathrm{DD}$ & $16.9 \mathrm{MMB}$ \\
\hline & 3 & $12.1 \mathrm{~B} \mathrm{D}$ & 61.1 МВ В & 44.3 B D & $51.3 \mathrm{~L} \mathrm{D}$ & $36.1 \mathrm{MMB}$ \\
\hline & 5 & $14.4 \mathrm{~B} \mathrm{D}$ & 101.9 МВ В & 58.8 B D & $68.8 \mathrm{~L} \mathrm{D}$ & $58.0 \mathrm{MMB}$ \\
\hline \multirow[t]{3}{*}{ Des. III } & 1 & 13.2 B B D & $45.0 \mathrm{MB}$ & $21.6 \mathrm{~B} \mathrm{D}$ & $34.3 \mathrm{D}$ & $13.4 \mathrm{MB}$ \\
\hline & 3 & $16.0 \mathrm{~B} \mathrm{~B} \mathrm{D}$ & $78.6 \mathrm{MB}$ & 52.1 B D & 48.7 L D D & $40.3 \mathrm{MM} \mathrm{B}$ \\
\hline & 5 & $19.2 \mathrm{~B}$ & $117.4 \mathrm{MB}$ & 71.7 B D D & 69.1 LDD & $52.8 \mathrm{M}$ \\
\hline \multirow[t]{3}{*}{ Des. IN } & 1 & $15.1 \mathrm{~B} \mathrm{D}$ & $24.9 \mathrm{MB}$ & 33.7 B D D & $24.3 \mathrm{~L} \mathrm{DD}$ & $16.4 \mathrm{MMB}$ \\
\hline & 3 & $16.0 \mathrm{~B} \mathrm{D}$ & $70.1 \mathrm{MB}$ & 61.0 B D D & $43.7 \mathrm{~L} \mathrm{D}$ & $38.9 \mathrm{M}$ \\
\hline & 5 & $15.4 \mathrm{~B} \mathrm{D}$ & $111.6 \mathrm{MB}$ & 79.7 B D D & $63.9 \mathrm{~L} \mathrm{D}$ & $57.2 \mathrm{M}$ \\
\hline \multirow[t]{3}{*}{ Des. $V$} & 1 & $10.7 \mathrm{~B} \mathrm{D}$ & $26.9 \mathrm{MB} \mathrm{B}$ & 27.9 B D D & $25.2 \mathrm{LDD}$ & $24.6 \mathrm{M}$ \\
\hline & 3 & $16.4 \mathrm{BD}$ & $66.1 \mathrm{MB} \mathrm{B}$ & 68.1 B D D & 37.3 L D D & $53.8 \mathrm{M}$ \\
\hline & 5 & $18.2 \mathrm{~B} \mathrm{D}$ & $103.6 \mathrm{MB}$ & 91.8 B D D & $61.1 \mathrm{LD}$ & $86.0 \mathrm{M}$ \\
\hline \multirow[t]{3}{*}{ Des. II } & 1 & $14.7 \mathrm{~B}$ & $40.1 \mathrm{MB} \mathrm{B}$ & 30.7 B B D & 8.9 L L D & $33.2 \mathrm{MML}$ \\
\hline & 3 & $25.6 \mathrm{~B}$ & $79.8 \mathrm{MB}$ & 56.6 B B D & $16.1 \mathrm{~L} \mathrm{LD}$ & $69.8 \mathrm{M}$ \\
\hline & 5 & $32.6 \mathrm{~B}$ & $142.0 \mathrm{MB}$ & 73.7 B B D & 20.0 L L D & $108.7 \mathrm{M}$ \\
\hline \multirow[t]{3}{*}{ Des. VII } & 1 & $9.7 \mathrm{~B}$ & $30.1 \mathrm{MB} \mathrm{B}$ & 19.7 B D & $12.3 \mathrm{~L} \mathrm{D}$ & $33.3 \mathrm{M}$ \\
\hline & 3 & $12.6 \mathrm{~B}$ & 78.7 M B B & 33.9 B D & $22.3 \mathrm{~L} \mathrm{D}$ & $62.2 \mathrm{M}$ \\
\hline & 5 & $12.7 \mathrm{~B}$ & $116.3 \mathrm{MB}$ & $60.0 \mathrm{~B} \mathrm{D}$ & $38.0 \mathrm{~L} \mathrm{D}$ & $106.4 \mathrm{M}$ \\
\hline \multirow[t]{3}{*}{ Des. VIII } & 1 & $12.0 \mathrm{~B}$ & $72.0 \mathrm{MB} \mathrm{B}$ & 40.4 B D D & $40.0 \mathrm{~L} \mathrm{D}$ & $18.1 \mathrm{MMB}$ \\
\hline & 3 & $14.0 \mathrm{~B}$ & 114.4 MB B & $67.6 \mathrm{D}$ & $143.3 \mathrm{~L} \mathrm{~L} \mathrm{D}$ & $44.3 \mathrm{MML}$ \\
\hline & 5 & 17.3 B D & $150.0 \mathrm{MB} \mathrm{B}$ & $96.8 \mathrm{D}$ & 190.9 L L D & $65.0 \mathrm{MML}$ \\
\hline \multirow[t]{3}{*}{ Des. IX } & 1 & $10.0 \mathrm{M}$ & $44.0 \mathrm{MB}$ & 26.7 B D D & $77.8 \mathrm{~L}$ & $39.0 \mathrm{MML}$ \\
\hline & 3 & $11.1 \mathrm{MMB}$ & $127.8 \mathrm{MB}$ & 74.6 B D D & 193.3 L L D & $78.1 \mathrm{MML}$ \\
\hline & 5 & $24.2 \mathrm{MB}$ & $177.1 \mathrm{MB}$ & $-\quad-$ & 264.4 L L D & $98.8 \mathrm{M}$ \\
\hline
\end{tabular}


Table 1-2 Magnitude $(\mu \mathrm{m})$ and direction of the abutment tooth movement

\begin{tabular}{|c|c|c|c|c|c|c|}
\hline \multirow{2}{*}{\multicolumn{2}{|c|}{ Design Load $(\mathbf{k g})$}} & \multicolumn{5}{|c|}{ Loading point } \\
\hline & & \multirow{2}{*}{$\frac{\text { (2) }}{2.0 \mathrm{MB}}$} & \multirow{2}{*}{$\frac{\text { (4) }}{27.7 \mathrm{MB}}$} & \multirow{2}{*}{$\frac{6}{6.4 \mathrm{D}}$} & \multirow{2}{*}{$\frac{\text { (8) }}{10.4 \mathrm{LD}}$} & \multirow{2}{*}{$\frac{110}{11.7 \mathrm{MMB}}$} \\
\hline Des. I & 1 & & & & & \\
\hline & 3 & $6.3 \mathrm{MB}$ & $61.9 \mathrm{MB}$ & 25.7 B D D & $25.7 \mathrm{~L} \mathrm{D}$ & $28.1 \mathrm{M}$ \\
\hline & 5 & $7.0 \mathrm{MB}$ & $97.3 \mathrm{MB}$ & 49.0 B D D & 40.7 L D D & $55.1 \mathrm{M}$ \\
\hline \multirow[t]{3}{*}{ Des. II } & 1 & 5.3 B B D & $23.0 \mathrm{MB}$ & 20.1 B D D & $25.0 \mathrm{LDD}$ & $10.7 \mathrm{MMB}$ \\
\hline & 3 & 7.4 B B D & $80.1 \mathrm{MB}$ & 24.7 B D D & $36.9 \mathrm{LDD}$ & $25.4 \mathrm{MMB}$ \\
\hline & 5 & $11.7 \mathrm{~B}$ & $130.3 \mathrm{MB}$ & 58.9 B D D & $54.3 \mathrm{~L} \mathrm{DD}$ & $41.3 \mathrm{MMB}$ \\
\hline \multirow[t]{3}{*}{ Des. 目 } & 1 & $12.9 \mathrm{~B} \mathrm{D}$ & $33.4 \mathrm{MMB}$ & 25.0 B D D & $23.8 \mathrm{~L} \mathrm{DD}$ & $18.0 \mathrm{MB} \mathrm{B}$ \\
\hline & 3 & 13.0 B B D & $62.8 \mathrm{MB}$ & 51.7 B D D & $34.6 \mathrm{~L} \mathrm{DD}$ & $33.2 \mathrm{MMB}$ \\
\hline & 5 & 14.0 B B D & $80.9 \mathrm{MB}$ & 72.8 B DD & 41.3 L D D & $43.4 \mathrm{M}$ \\
\hline \multirow[t]{3}{*}{ Des. $\mathbb{N}$} & 1 & $11.7 \mathrm{~B} \mathrm{DD}$ & $17.6 \mathrm{MB}$ & $37.6 \mathrm{D}$ & $20.0 \mathrm{LDD}$ & $9.3 \mathrm{MB} \mathrm{B}$ \\
\hline & 3 & $12.0 \mathrm{~B} \mathrm{D}$ & $55.6 \mathrm{MB}$ & $61.2 \mathrm{D}$ & 31.6 L D D & $27.1 \mathrm{M}$ \\
\hline & 5 & $10.7 \mathrm{~B} \mathrm{D}$ & $93.2 \mathrm{MB}$ & 77.9 B D D & $39.8 \mathrm{LDD}$ & $38.2 \mathrm{M}$ \\
\hline \multirow[t]{3}{*}{ Des. $V$} & 1 & $10.7 \mathrm{MMB}$ & $29.0 \mathrm{MB}$ & $27.6 \mathrm{D}$ & $10.9 \mathrm{~L} \mathrm{D}$ & $30.8 \mathrm{M}$ \\
\hline & 3 & $18.0 \mathrm{MMB}$ & $68.2 \mathrm{MB}$ & $54.2 \mathrm{D}$ & $16.7 \mathrm{~L} \mathrm{D}$ & $70.7 \mathrm{M}$ \\
\hline & 5 & $18.3 \mathrm{MMB}$ & $106.9 \mathrm{MB}$ & $79.9 \mathrm{D}$ & $31.0 \mathrm{LD}$ & $100.9 \mathrm{M}$ \\
\hline \multirow[t]{3}{*}{ Des. V } & 1 & $1.9 \mathrm{MB}$ & $38.7 \mathrm{MB}$ & $19.7 \mathrm{~B} \mathrm{DD}$ & 9.7 L L D & $27.3 \mathrm{M}$ \\
\hline & 3 & $11.4 \mathrm{MB}$ & $69.7 \mathrm{MB}$ & 36.8 B D D & $13.0 \mathrm{~L} \mathrm{~L} \mathrm{D}$ & $65.2 \mathrm{M}$ \\
\hline & 5 & $15.3 \mathrm{MMB}$ & $118.1 \mathrm{MB}$ & 59.7 B DD & $18.0 \mathrm{~L} \mathrm{~L} \mathrm{D}$ & $118.0 \mathrm{M}$ \\
\hline \multirow[t]{3}{*}{ Des. VI } & 1 & $6.0 \mathrm{MB}$ & $44.0 \mathrm{MB}$ & $13.4 \mathrm{LDD}$ & 7.3 L L D & $38.1 \mathrm{M}$ \\
\hline & 3 & $6.7 \mathrm{MB}$ & $93.4 \mathrm{MB}$ & 28.8 B D D & 11.7 L L D & $78.3 \mathrm{M}$ \\
\hline & 5 & $10.7 \mathrm{MB}$ & $130.6 \mathrm{MB}$ & 49.7 B D D & $15.9 \mathrm{~L} \mathrm{~L} \mathrm{D}$ & $114.3 \mathrm{M}$ \\
\hline \multirow[t]{3}{*}{ Des. VIII } & 1 & $13.7 \mathrm{D}$ & $22.9 \mathrm{MB}$ & $47.6 \mathrm{~L} \mathrm{DD}$ & 58.9 L D & $11.2 \mathrm{MML}$ \\
\hline & 3 & $13.8 \mathrm{~L} \mathrm{~L} \mathrm{D}$ & $59.3 \mathrm{MB}$ & $72.4 \mathrm{LDD}$ & 74.4 L L D & $44.7 \mathrm{MML}$ \\
\hline & 5 & $15.2 \mathrm{LD}$ & $101.6 \mathrm{MB}$ & $76.0 \mathrm{D}$ & $91.1 \mathrm{LLD}$ & $85.0 \mathrm{MML}$ \\
\hline \multirow[t]{3}{*}{ Des. IX } & 1 & $11.3 \mathrm{~L}$ & - & 26.1 B D D & 48.0 L D & $45.1 \mathrm{M}$ \\
\hline & 3 & $27.4 \mathrm{ML}$ & - & $68.6 \mathrm{D}$ & 175.6 L L D & $90.9 \mathrm{M}$ \\
\hline & 5 & $39.0 \mathrm{MML}$ & - & -- & $-\quad-$ & $119.4 \mathrm{M}$ \\
\hline
\end{tabular}

(MB) 方向へ変位し, 復元経路は概して荷重時経路の 近心を回り込んで出発点に戻るケースが多かった。例外 的に荷重時経路と交差して復元するものや遠心を回り込 んで復元するものもあった。また，デザインIVに $5 \mathrm{~kg}$ の荷重を近心から負荷した場合のように変位量が著しく 大きくなり計測不可能となる場合もあった。

遠心から負荷した場合には，ほぼ雪槽堤の走行状態と 平行に近心へ変位した．その過程で遠心歯荷重時, デザ イン V，Vのように渦巻き状の動きをしながら傾斜した り，近・遠心歯荷重時のデザインIXのように荷重時経路 と戻り経路が交差したり，さらには荷重除去の遅速の度 合いによって鉤菊の挙動に差異がみられるものもあっ
た。

垂直的に負荷した場合には，ほとんどがそのまま荷重 時経路を逆行して復元した.

Fig. 13 で概観できるように近心歯荷重時と遠心䈄荷 重時の挙動を比較した場合には，遠心方向からの荷重時 ならびに重直方向からの荷重時を除いては近心歯に負荷 した場合が遠心米に負荷した場合よりも，幾分大きく広 範囲に変位している様子が見受けられる．乙の近・遠心 蒾荷重時の鉤歯の变位量の差を統計的に検定した結果が Table 4 である. 遠心曾荷重時の変位量が近心曾荷重 時よりも有意に大きかったのは, 義歯床を削除したデザ イン Xにおいて重直荷重時あるいは遠心からの荷重を加 


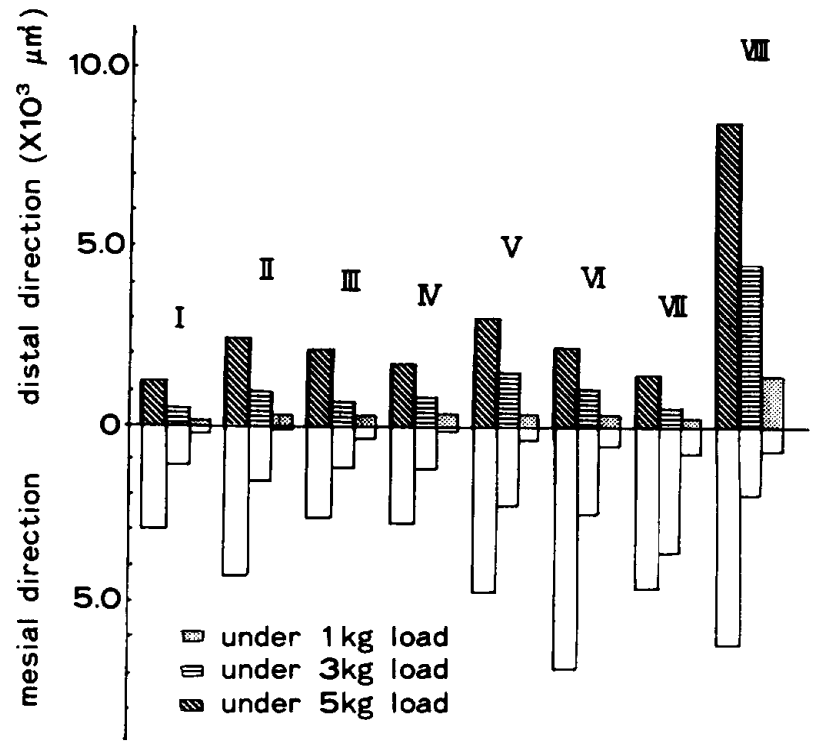

Fig. 9 Movement areas of the abutment tooth.

Table 2 Maximum areas surrounded by the traces of the abutment tooth movement $\times 10^{3}\left(\mu \mathrm{m}^{2}\right)$

\begin{tabular}{|c|c|c|c|}
\hline Design & Distal area & Mesial area & Total area \\
\hline Des. I & $1.2(100)$ & 3.0 & $4 \cdot 2(100)$ \\
\hline Des. II & $2.4(200)$ & 4.3 & $6.7(160)$ \\
\hline Des. III & $2.2(180)$ & 2.8 & $5.0(120)$ \\
\hline Des. $\mathrm{N}$ & $1.8(150)$ & 3.0 & $4.8(110)$ \\
\hline Des. V & $3.0(250)$ & 4.9 & $7.9(190)$ \\
\hline Des. VI & $2.1(175)$ & 6.8 & $8.9(210)$ \\
\hline Des. VII & $1.3(110)$ & 4.6 & $5.9(140)$ \\
\hline Des. VII & $8.8(730)$ & 6.2 & $15.0(360)$ \\
\hline Des. IX & - & 15.4 & - \\
\hline
\end{tabular}

( ) : percentage to Des. I

えた場合，間接維持装置および連結装置すべてを切除し たデザインVIII遠心から負荷した場合，ならびにデザィ ンI 抢よびリング鈎々先のみ切除したデザイン II舌側 から負荷した場合のみで，他の場合はいずれも近心雪荷 重時の鉤崡変位量の方が大きくなった．

\section{B . 反対側荷重に上る鈎歯の挙動}

鉤崡の反対側にある第 1 大臼歯相当部に垂直的ならび に煩・舌側的の 3 方向から急荷した場合の鍃菌 $4 \mid$ の挙 動もデザインVIIで観察, 記録したが，いずれの荷重成 分でも変位量は極めて小さかったために図上にはデザイ ンごとに区別して表示し得なかった〈Fig. 15).しかし

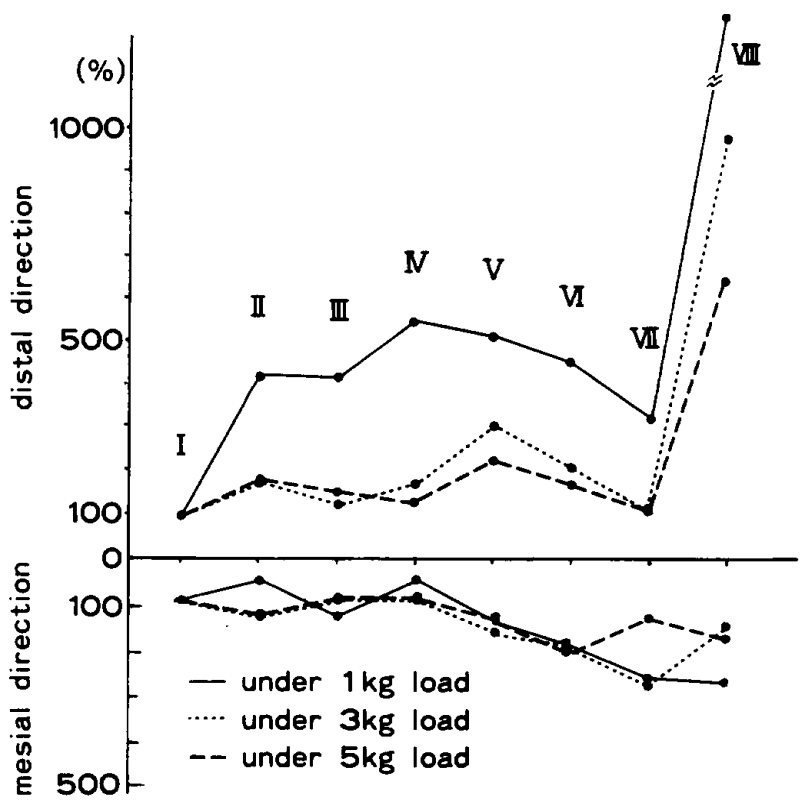

Fig. 10 Percentage changes in the movement areas of the abutment tooth. The area in design I was assigned by the value of $100 \%$.

ながら, 各荷重成分下での鈎歯の挙動には微妙な差異が 認められた。

垂直的に負荷した場合には，デザイン I から III では銁

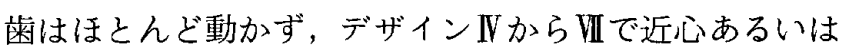
舌側へわずかに傾斜した。しかし単純な変位ではなく, 同一部位に停滞した状態で振動しながらわずかに変位す る状態が MKG 軌跡スロー再確認機構によって観察さ れた。

舌側から負荷した場合，デザイン I から正ではわずか にLD方向への変位がみられ, 荷重量の増加によって幾

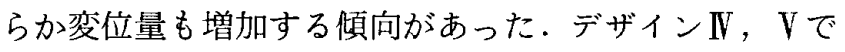
はL方向に変わり，デザインVI，VII゙は再びデザイン I から III場合に近い LLD 方向に変わった．またデザイ ンVI，UIではデザインVまでのものに比べて変位量がや や大きくなった，舌側に負荷した場合は垂直的に負荷し た場合と比較していずれもわずかながら大きくはなった が，鉤雬と同側にある義畨床上に舌側から負荷した場合 の変位量に比べれば極めて小さな動きであった．しかし 鈎菡に小さな変位しか与えなかったにもかかわらずデザ イン $\mathbb{V}$, Vのように荷重除去後に完全に復元し得ないも のもあった。

煩側から負荷した場合は，デザインIから IIIではほと んぞ動かず，デザイン $\mathbb{N} 、 V$ V遠心変位, デザイン $\mathrm{V}$, VIIT゙舌側によった遠心変位が認められたが極めて小さな 


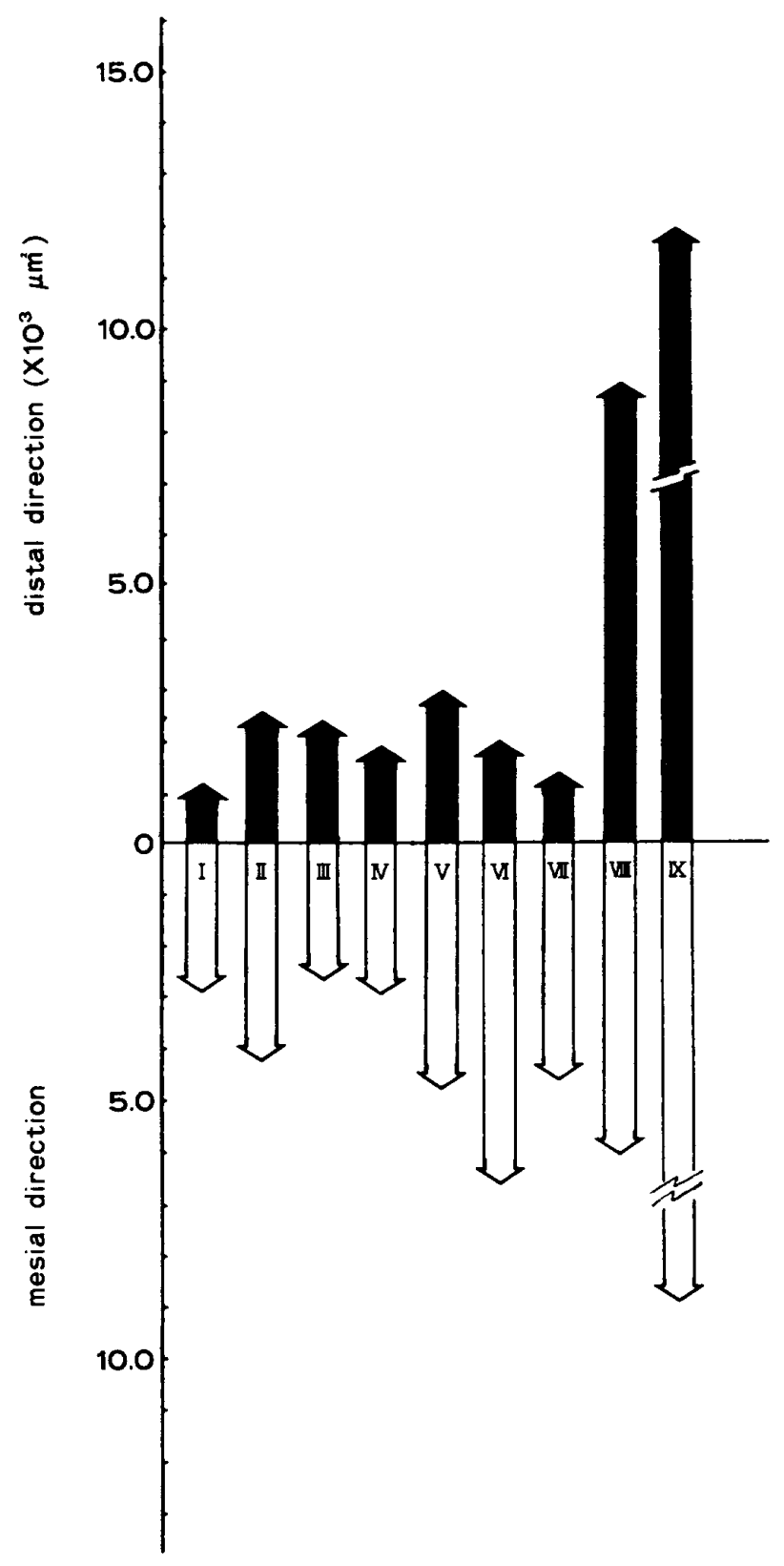

Fig. 11 Movoment areas of the abutment tooth under various loads.

ものであった。

いずれの場合も鈎曾の反対側への負荷は，鈎雨に極め てわずかな変位しか与えなかった。

C . 脱離力に上る鈎雨の挙動

鈎歯同側第 1 大曰菌相当部を垂直に上方へ引いた場合 の鉤幽の挙動は，各デザインとも変位量が小さく，その 上複雑な軌跡を描いたために反対側荷重時の場合々同 様にデザイン別にそれぞれの挙動を表示し得なかった (Fig. 16)。詳細に篗察した結果，デザインI ではやや 遠心寄りに舌側に変位する傾向があったが単純な変位で

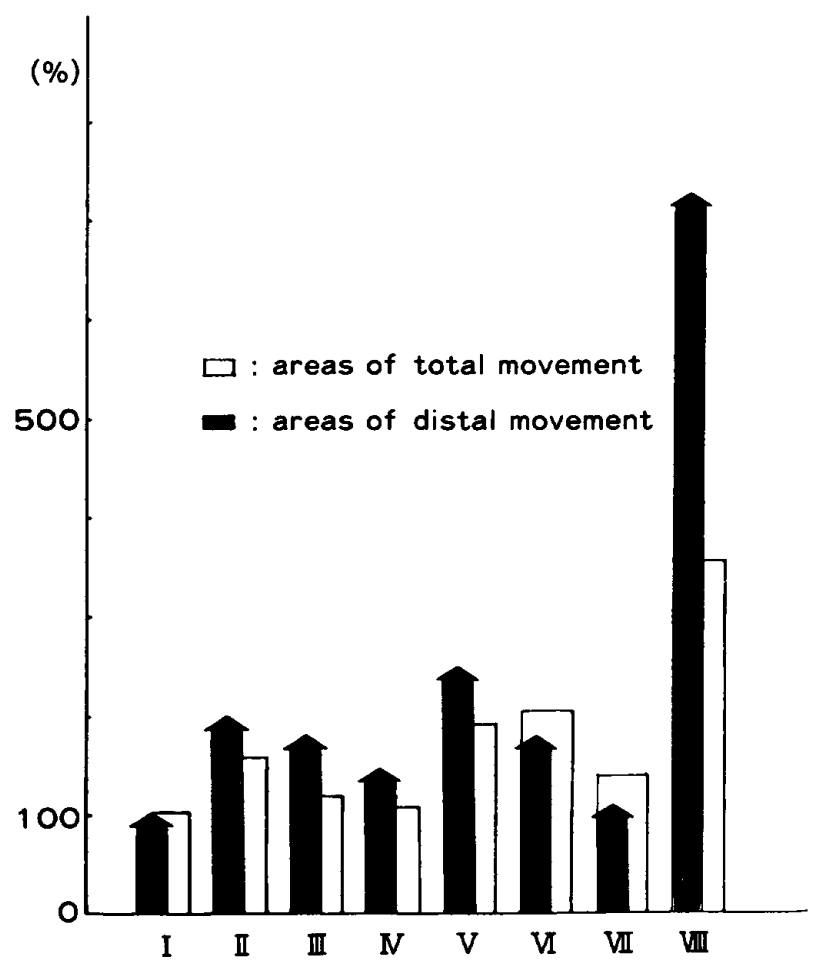

Fig. 12 Comparison of the movement areas of eight denture designs. The area in design I assigned by the value of $100 \%$.

はなく, 最大 $400 \mathrm{~g}$ でクラスプが銁菌から脱離するまで， 振動, 回転しながら変位する状態か観察され，その状態 は蛇行，重複した軌跡として描記された。

デザイン II， II では MLL 方向に変位した後，わずか に遠心に変位してクラスプが脱離した．そのときの最大 荷重量は250gであった。デザイン $\mathrm{N} ， \mathrm{~V}$ では近心に変 位した後，それぞれ舌側および遠心方向へターンする状 態を示した．デザインVI ではやや遠心寄りの LLD 方向 に変位し， $50 \mathrm{~g}$ 程度の力で簡単に脱離した。デザインVII もほぼ同様の挙動を示し，同側のクラスプが脱離した。 デザィン壮では先ず煩側に変位したのち近心に動き，つ いで遠心にターンしてクラスプが鉤菌から脱離し，変位 量は全てのデザインの中で最大であった。

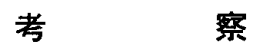

I ·計測装置の記録精度について

センサー・アレ一改良型においも検出用マグネットの 動きは MKG 記録上にそのまま再現されるわけではな く, 従来型に比較して小さくなったとはいえ, やはり Fig. 5 亿示されたようなひずみが羿められた。これは マグネットの 3 次元的な動きによって起てる磁場の変化 


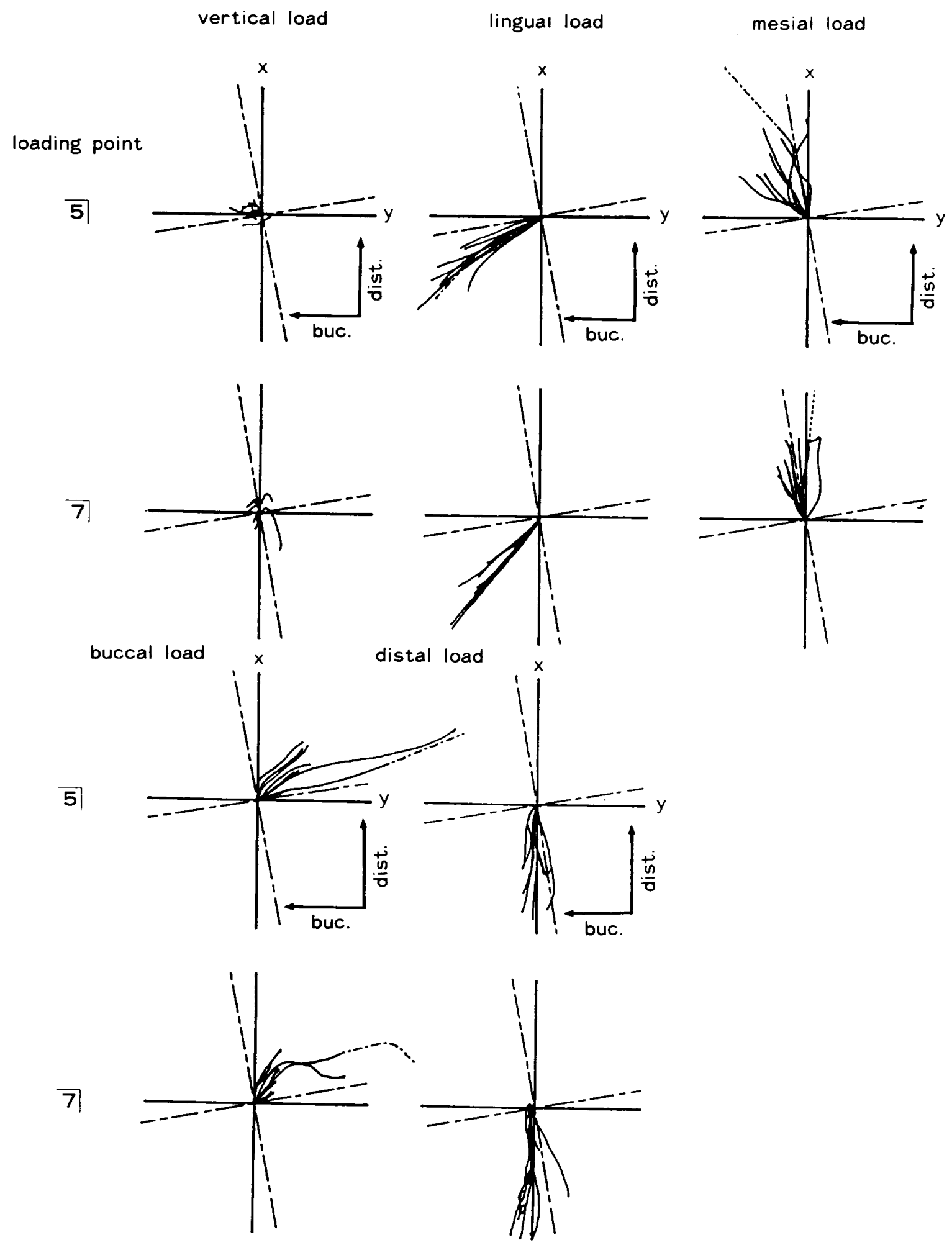

Fig. 13 Comparison of the traces of the abutment tooth movement in design I - IX caused by loading ( $5 \mathrm{~kg}$ ) on the second premolar and the second molar. Chain line curves denote the traces by $3 \mathrm{~kg}$-loading since the records by $5 \mathrm{~kg}$-loading went out of scale. 
Table 3 Results of $t$-tests for the significance of difference in the distal movement of the abutment tooth between the designs employed

(Load : $5 \mathrm{~kg}$ )

\begin{tabular}{|c|c|c|c|c|c|c|c|c|c|}
\hline \multirow{8}{*}{ Loading point (5) } & Des. I & - & & & & & & & \\
\hline & Des. II & $* *$ & - & & & & & & \\
\hline & Des. III & $* *$ & $* *$ & - & & & & & \\
\hline & Des. IV & $* * *$ & $* *$ & $*$ & - & & & & \\
\hline & Des. V & $* *$ & $* *$ & $* *$ & $* *$ & - & & & \\
\hline & Des. VI & $* *$ & $* *$ & & & $* *$ & - & & \\
\hline & Des. VII & $* *$ & & $* *$ & $* *$ & $* *$ & $* *$ & - & \\
\hline & Des. VII & $* *$ & $* *$ & $* *$ & $* *$ & & $* *$ & $* *$ & - \\
\hline \multirow[t]{8}{*}{ Loading point (6) } & Des. I & - & & & & & & & \\
\hline & Des. II & $* *$ & - & & & & & & \\
\hline & Des. II & $* *$ & $* * *$ & - & & & & & \\
\hline & Des. IV & $* *$ & $* *$ & $*$ & - & & & & \\
\hline & Des. V & $* *$ & $* * *$ & $* *$ & & - & & & \\
\hline & Des. II & $* *$ & & $* *$ & $* *$ & $* *$ & - & & \\
\hline & Des. VII & & $* *$ & $* *$ & $* *$ & $* *$ & $* *$ & - & \\
\hline & Des. VII & $* *$ & $* *$ & & & & $* *$ & $* *$ & - \\
\hline \multirow[t]{8}{*}{ Loading point (7) } & Des. I & - & & & & & & & \\
\hline & Des. II & $* *$ & - & & & & & & \\
\hline & Des. III & $* *$ & & - & & & & & \\
\hline & Des. IN & $* *$ & & & - & & & & \\
\hline & Des. V & $* *$ & $*$ & $*$ & & - & & & \\
\hline & Des. VI & $* *$ & $* *$ & $* *$ & $* *$ & $* *$ & - & & \\
\hline & Des. VI & $*$ & $* *$ & $* *$ & $* *$ & $* *$ & $* *$ & - & \\
\hline & Des. VIII & $* *$ & $* *$ & $* *$ & $* *$ & $* *$ & $* *$ & $* *$ & - \\
\hline \multirow[t]{8}{*}{ Loading point (8) } & Des. I & - & & & & & & & \\
\hline & Des. II & $* *$ & - & & & & & & \\
\hline & Des. III & & $* *$ & - & & & & & \\
\hline & Des. $\mathbf{N}$ & & $* *$ & & - & & & & \\
\hline & Des. V & $* *$ & $* *$ & $* *$ & $* *$ & - & & & \\
\hline & Des. II & $* *$ & $* *$ & $* *$ & $* *$ & $* *$ & - & & \\
\hline & Des. VII & $* *$ & $* *$ & $* *$ & $* *$ & $* *$ & & - & \\
\hline & Des. VIII & $*$ & $* *$ & & $*$ & $* *$ & $* * *$ & $* *$ & - \\
\hline
\end{tabular}

$* * \mathrm{p}<0.01 \quad * \mathrm{p}<0.05$

を 8 個のセンサーで感知し，それを電気的に变換して被 験体の挙動を表示する過程で磁力線の放散状態によって 生ずる現象であろう。しかし，Morikawa ら（1988） 38) や本研究の場合の上うに，鉤歯の変位に相当するマ グネットの動きを補正用格子の上に重ね合わせ，各軸か らの相対的な距離を直交座標上にプロットし直すととに よってほぼ正確な鈎歯の動きをあらわすととが可能であ るので, MKG は鈎歯の挙動を解析するためにも有用な
手段であると考えられる。

II · 各種成分を含む鉤狊の挙動について

遊離端義蒾，ことに下顎症例に扔ける設計上の最大の 問題点は, 義雪の維持安定を図りながら銁菌歯根膜と顎 堤粘膜の被圧縮量の差をいかに処理するかということで あろう，鈎菌を後方へ率引儿鉤㐘損傷を引き起てす最大 の原因は, 乙れら両組織間の被压縮量の差にあるとの考 光に基づき，種々の方法1,21)が提唱されている.すな 


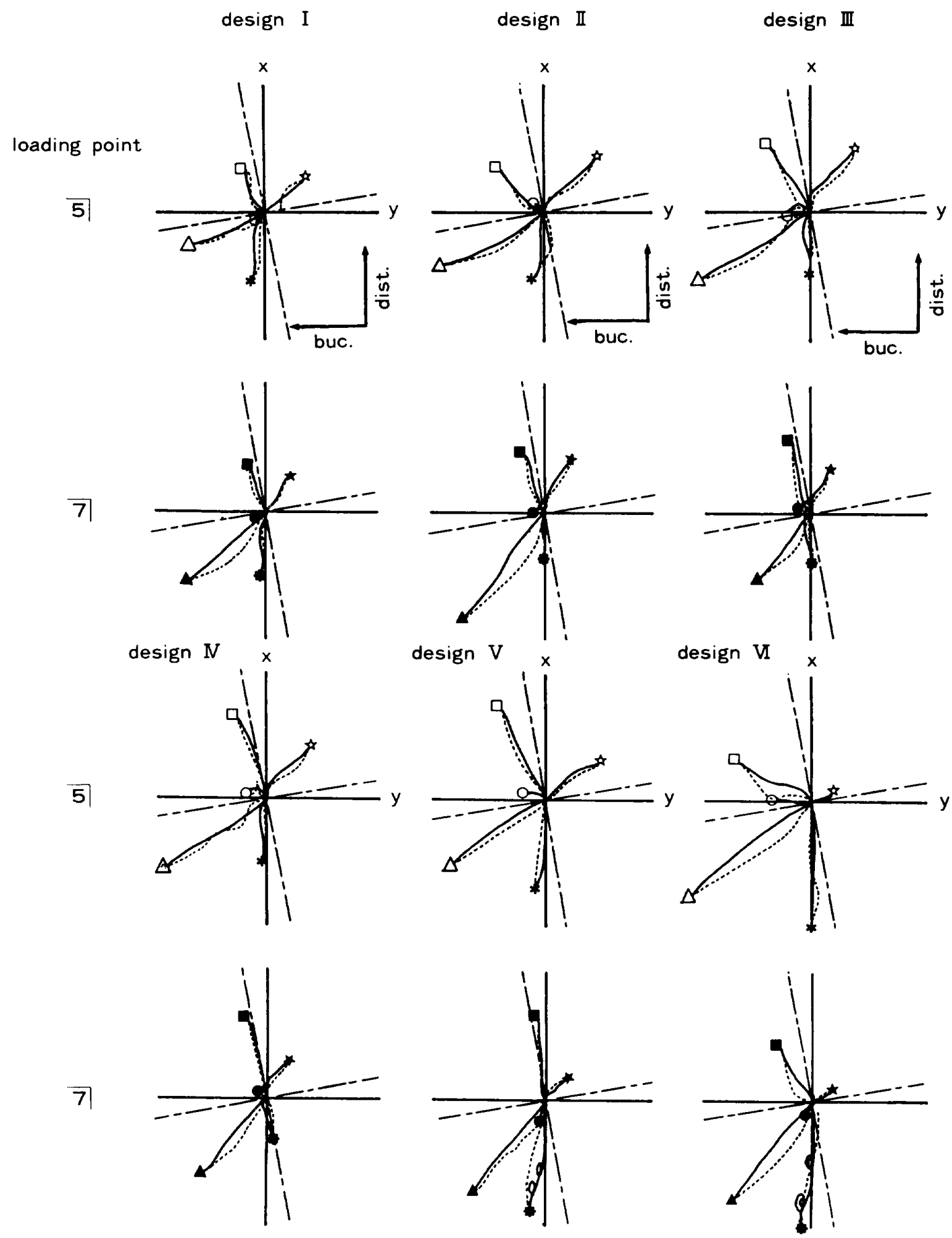

Fig. 14-1 Traces of the abutment tooth movement by $5 \mathrm{~kg}$-loading and after off-loading drawn by solid and dotted lines, respectively. 


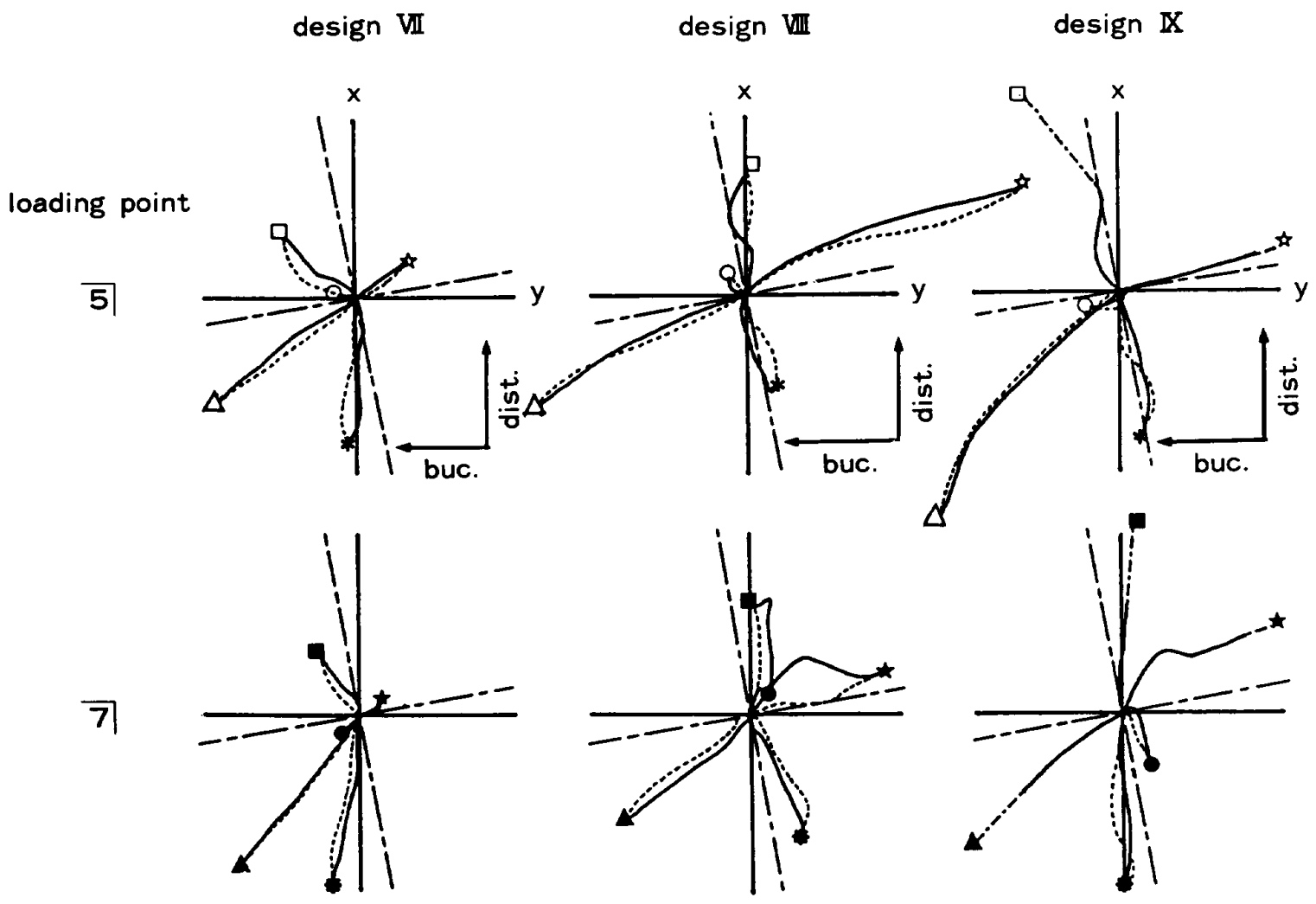

loading point
0 : (1)
- : (2)
$\Delta:$ (3)
$\Delta:$ : (4)
ㅁ: (5)
- : (6)
42: (7)
$4:$ :
* : (9)
- : (10)

Fig. 14-2 Traces of the abutment tooth movement by $5 \mathrm{~kg}$-loading and after off-loading drawn by solid and dotted lines, respectively. Chain line curves denote the traces by $3 \mathrm{~kg}$-loading since the records by $5 \mathrm{~kg}$ loading went out of scale. 

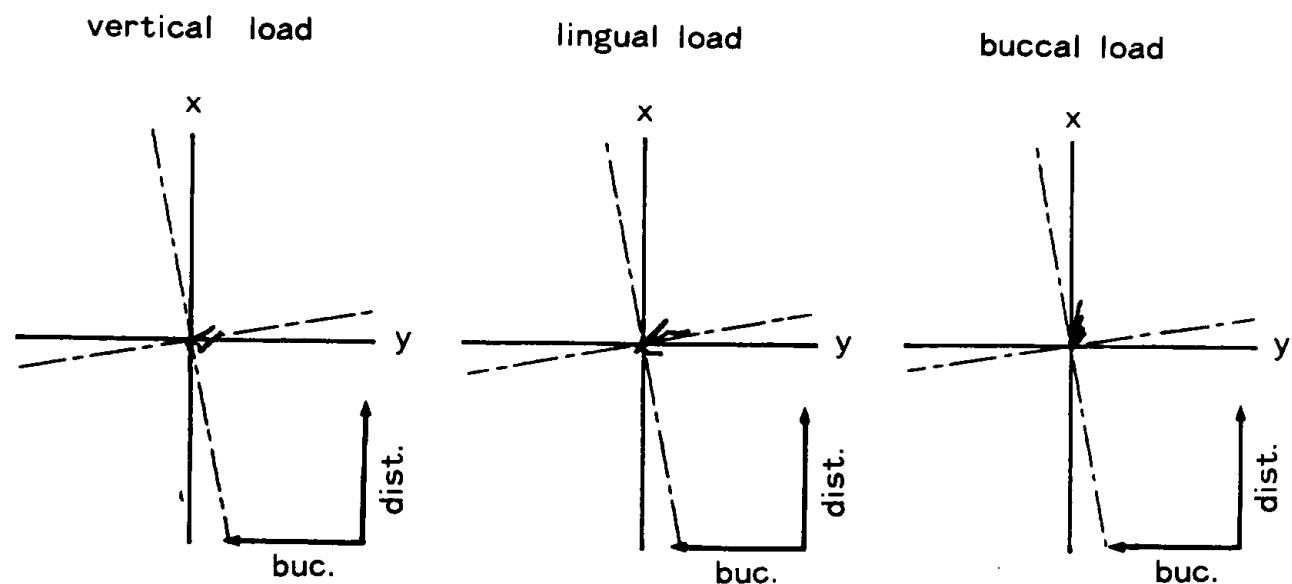

Fig. 15 Traces of the abutment tooth movement by loading on the other side of the arch.

Table 4 Comparison of the abutment tooth movement between the equivalent loading on the second premolar and on the second molar

\begin{tabular}{|c|c|c|c|c|c|}
\hline \multirow{2}{*}{ Designs } & \multicolumn{5}{|c|}{ Loading point } \\
\hline & (1)-(2) & (3)-(4) & (5)-(6) & (7)-8) & (9)-(10) \\
\hline & $* *$ & $*$ & & & \\
\hline \multirow[t]{2}{*}{ Des. I } & $>$ & $<$ & $<$ & $>$ & $>$ \\
\hline & & $* *$ & & $* *$ & $* *$ \\
\hline \multirow[t]{2}{*}{ Des. II } & $>$ & $<$ & $<$ & $>$ & $>$ \\
\hline & $*$ & $* *$ & & $* *$ & $*$ \\
\hline \multirow{2}{*}{ Des. III } & $>$ & $>$ & $<$ & $>$ & $>$ \\
\hline & $* *$ & $* *$ & & $* * *$ & $* *$ \\
\hline \multirow[t]{2}{*}{ Des. IV } & $>$ & $>$ & $>$ & $>$ & $>$ \\
\hline & & & $* *$ & $* *$ & \\
\hline \multirow[t]{2}{*}{ Des. V } & $>$ & $<$ & $>$ & $>$ & $<$ \\
\hline & $* *$ & $*$ & $* *$ & & \\
\hline \multirow[t]{2}{*}{ Des. VI } & $>$ & $>$ & $>$ & $>$ & $<$ \\
\hline & $* *$ & $*$ & $* *$ & $* *$ & \\
\hline \multirow[t]{2}{*}{ Des. VII } & $>$ & $<$ & $>$ & $>$ & $<$ \\
\hline & $* *$ & $* *$ & $*$ & $* *$ & $* *$ \\
\hline \multirow[t]{2}{*}{ Des. VIII } & $>$ & $>$ & $>$ & $>$ & $<$ \\
\hline & $* *$ & $* *$ & & & $* *$ \\
\hline Des. IX & $<$ & $>$ & $>$ & $>$ & $<$ \\
\hline
\end{tabular}

(1)(3)(5)(7)(9): loading on the second premolar (2)(4)(6)(8) : loading on the second molar $* * \mathrm{p}<0.01 \quad * \mathrm{p}<0.05$

わち，直接咬合庄を受ける咬合面の面積を縮小する方 法 $^{1,2}{ }^{2}$ ，義歯床面積を㹡大して単位面積当たりの咬合 王を軽減し，沈下しにくくする方法ならびに可及的に多 数蒾を鉤菌として広範囲に咬合力の配分を図る方法 ${ }^{3-}$

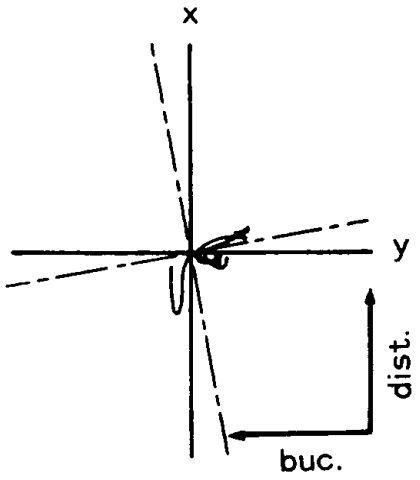

Fig. 16 Traces of the abutment tooth movement by appling dislodging force.

10)，鉤歯より遠心にある歯ほど回転トルクが強くなる ため遠心端の人工歯を排列しなかったり，咬合面の小さ い他の人工歯を代用する方法 ${ }^{1,2}, 11$ ，あらかじめ咬合 圧を顎堤に与えて印象し機能時の顎堤粘膜部分の沈下量 を少なくするアルタード・キャスト法12-141，さらには 種々の緩圧機構を応用する方法18-211などがある。乙れ らは主として義㐘部へ垂直的な荷重が加わった場合の鉤 蒾歯根膜への影響を重視した結果生じたものと考えられ る.しかしながら，Fig.13でもわかるように，垂直的 荷重下での鈎蒾の変位は極めて小さく，側庘成分を含む 荷重下の約 $1 / 7 の$ 変位量しか認められなかったという事実 から垂直荷重時よりもむしろ側方成分を含む咬合圧に対 抗し得る工夫ないしは装置の開発が必要であろう。との 図からも明らかなように重直荷重時，舌側荷重時ならび に遠心荷重時には，鉤歯は近心に傾斜する傾向が強い が，口腔内では鉤歯近心に隣接する歯によって鉤歯は近 
心に傾斜しにくいので，鉤画菌根膜への為害性は少ない ものと思われる．しかし，銁曾を遠心方向へ牽引する煩 側ならびに近心からの力の作用に対しては何らかの考慮 が必要であろう，それには，多数蒾を鈎茵にする方法や 調和のとれた平衡咬合状態を与える方法などが挙げられ る、まず，多数蔝を銁雨にする方法では，Fig. 11 にみ られるようにデザイン I が最も鈎柬の変位を抑制するの に有効であるが，鈎爾霜根膜損傷に最も関与していると 考えられる近心および煩側からの力のうち，後者の力に 対してはデザィンVI，YIIの方が小さく（Fig.14），さら に臨床的に異物感を考慮にいれた場合，デザイン VI， III は極めて有利なデザインであろう。臨床的に，下顎片側 遊離端義菌では反対側に間接維持装置を延ばし，第 1 ， 2 小曰歯に双歯鉤を設定してりンガルバーあるいはりン ガルプレートで連結することが多いが，乙の実験結果か らも，いわば習慣的に用いられている下頡片側遊離端症 例のデザインが，図らずも力学的にも有効な方法である ことが示唆された。 また，オリジナルなデザインIの全 変位領域ならびに遠心方向変位領域をそれぞれ 100 とし た場合の各デザインの変位量を表示した Fig. 12 からも これら両デザインの特殊性がわかる，つまり，全変位領 域は義䨑の安定性にも関連があると考えられるが，遠心 方向への変位領域が大きいことはいうまでもなく，鈎菌 に対する為害性が大であることを表している．デザイン VIIでは, 全変位領域ではデザイン II や IV に比べて大きい が，遠心方向への変位領域ではデザイン I とほとんど変 わらず小さいために，鈎菌の為害性に加えて異物感を重 視して考えた場合には極めて望ましいデザインであるこ とが，乙の図からも理解できるであろう。また，デザイ ン II, III, IV, V, Uからさらに維持装置等を切除した デザイン叫が，かえって小さい遠心方向への変位量しか 示していないというととから対側の犬歯，小臼菌部は菌 列弓上の屈曲点（turning point）として重要な役割を

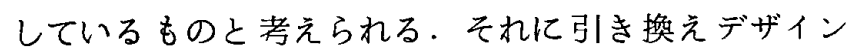
证は極めて不安定な義歯形態であることが Fig. 9，10

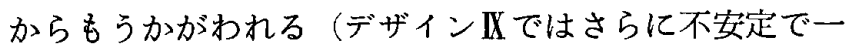
部, 計測不可能のため, 図より除外).乙れらの図にも みられるように，デザイン I では $1 \mathrm{~kg}$ 荷重時ではほと んど变位しないが，デザイン怔では小さな負荷に対して も容易に変位を来たすために， $1 \mathrm{~kg}$ 荷重時のデザイン Iに対する比率が大きく表示されている．しかし，最大 荷重の $5 \mathrm{~kg}$ ではデザインIにおいてもかなりの変位量 を示したために，比率としては小さくなっいる.

つぎ平衡咬合の付与については, 空口時, 咀嚼終末
時における偏心運動時での非作業側咬頭干渉は天然㐘に とって重大な為害性があるとされているが，下纇遊離端 義歯の場合もとれと同じととが考えられる．天然歯にお いては，偏心運動時の咬頭干渉によって生ずる水平的な 力が，歯根膜に対して外傷的に㗢くとされ，フルバラン スは禁忌とされているが40)，遊離端義歯の場合でも本 実験で明らかになったように，近心および煩側的な力に 対して鈎䨑に大きな後方率引力を発現させている 13）。乙の率引力を発現させているのが，臨床的にい光 ば下顎前進運動時の近心からの力と側方運動時における 作業側煩側咬頭の煩側からの力であり，そのような咬交 時接触がある場合には鈎歯損傷の危険性が考えられる。 したがってての為害作用から鈎歯を保護しようとするこ とに主眼を置けば，てのような近心ならびに煩側からの 力が発現しないディスクルージョンの接触形態のものが 望ましい。

何ら咬合に異常を訴えていない患者の場合は患者固有 の咬合様式に従うということは咬合学の原則であるが, これら煩側ならびに近心からの力を最小限にして鈎歯を 保護するととを第一義的に考えた場合，遊離端義菌の場 合も天然歯の場合と同様，義䨑部による誘導や滑走は可 及的に避けて，残存天然歯部によるディスクルージョン が最良であろう。そのためにも，顆路と調和した適切な アンテリアーガイダンスを与えるととの重要性が本実験 結果加らも改めて示唆された。

Fig. 13 および Table 4 で明らかなように近心米荷 重時と遠心歯荷重時の鈎霜変位量を比較した場合，同一 荷重量で遠心柬に負荷した場合に有意に大きな変位を惹 起したのは極めて限定されたデザインおよび荷重方向に おいてに過ぎなかった，「咬合面の小さい人工苗を臼 柬部に用いると，小さな筋力によって食べ物を粉砕， 穿通させることが可能であり，銁蒾歯根膜ならびに顎 堤に伝達される咬合力も小さくてすむ」という考えに 基づき，遊離端義歯では小さな人工曾を用いるととを McCracken (1985) ${ }^{1}$ も推奖している. しかし，第 2 大 曰崡に負荷した場合，第 1 大曰歯に負荷した場合と類似 した挙動は示したが，銁米の挙動ははるかに小さかった という Frechette ら (1956)41’の実験結果ならびに本 実験結果から，遠心歯ほど小さい人工歯を用いるととの 必要性については，なお疑問があるように思われる。

一般には荷重量を増加すれば変位方向は変わらず変位 量のみが増大する傾向があり (Fig. 8，9）, 義霜構成 要素を漸次切除していくにしたがって小さな力によって も変位し易くなっていく状態が観察された（Fig. 10）。 
また，全変位領域に対する遠心方向への変位量の推移を 示す Fig. 11，12 から，とくに間接維持装置がある場合 は概して近心へ変位する傾向がみられたものが，間接維 持装置を切除したデザイン传では遠心へ変位する傾向が

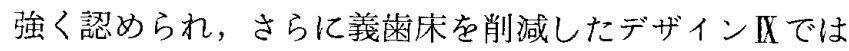
極めて不安定になることがわかった。このてとから遊離 端義歯設計時には間接維持装置を用いること，ならびに 可及的に義歯床面積を広くすることの重要性が再認識さ れた。

Frechette $(1956)^{41)}$, Kaires $(1956)^{42,43)}$, Henderson $(1967)^{44)}$ 抽よ゙ Cecconi ら $(1971)^{45}$ は，い ずれも鈎菌変位量は鈎歯と同側に負荷した場合が反対側 に負荷した場合より大きかったと報告してはいるが，本 実験結果（Fig. 15）とは異なり反対側に負荷した場合 では，かなり大きな変位量を記録している。乙の差異 は, 義歯デザイン, ならびに荷重量の違いによって生じ たものであろう。

荷重除去後と脱離力による挙動は従来, 全く観察され ていなかったが，Fig.14 のようにほとんど総てのデザ インで荷重時経路と荷重除去後の戻り経路は異なった軌 跡を描き，完全に復元し得ないものもあった．乙の完全 に復元し得なかったのはデザイン II， IIIみられ，鉤菌 からクラスプがわずかながら浮き上がった状態になって いたととから，シミューレーション材料の不完全な弾性 回復に依存するのではなく，不適切なクラスプの多用に よって，かえって復元しょうとする動きを干渉して生じ た現象であろう．また，脱離力作用下でもわずかな力で 脱離したり，完全に復元し得ないものも多かった：ての ように鈎柬の不完全な戻りや近心を回り込んで復元する

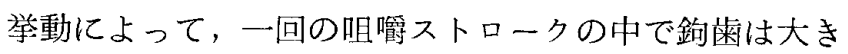
く回転的举動が生じ, 過大なストレスが加わっているて とが推測される。

Cecconi ら (1971 $)^{46}$ は, 澦堤の近・遠心的傾斜の違 いも鉤霜への重要な影響因子になり得ると述べている が, 本実験結果からもFig.13亿みられるように, 垂直 荷重時に近心への鈎䨑の変位が認められた．とくに遠心 㐘に負荷した場合には, 全てのデザインで近心への変位 があった．負荷すると先ず義粜床の沈下によって銁茵は 遠心に佂斜し，ついで義歯床が斜面をわずかに近心へ滑 って鉤歯を近心に押したものと思われる. 近心歯は顎堤 の平坦部あるいは部に位置していたために荷重時に義 歯床の滑走現象が抢てりにくかったのではないかと考え られる．近心への変位量がデザインIで極めて小さく， VIII， IXで大きくなったのも，前者は多数歯に連結されて
いたためにその動きが抑制され，後者は間接維持装置が 切断され片側だけの義荿に改造されたために滑走し易く なったものと思われる. Pendleton (1936) ${ }^{47}$ も述べて いるように臨床では顎堤の傾斜の度合い，顎堤粘膜や蒾 根膜の性状などの生物学的な要素による影響も考えられ るので, てれらのファクターによる影響については改め て検討の必要性があると考える.

\section{結論}

Kennedy II 級 1 類のシミュレーション・モデル上に さまざまな方向成分を含む荷重を加え，パーシャル・デ ンチャー・デザィンを変えていった場合の銁茵の 3 次元 的な挙動を MKGによって分析した結果, 以下のような 結論を得た。

1 ：垂直的に負荷した場合の鈎㐘変位量は, 側方成分 を含む荷重時の変位量に比べて著しく小さかった。

2 ：荷重量が増加しても，変位方向はほとんど変化せ ず，変位量のみが増大する傾向があった。

3 ）義歯床遠心端部分に負荷した場合は，銁菌に近い 部分に負荷した場合よりも，概して鈎雨の変位量は小さ かった.

4）銁歯損傷に最も関連のあると考えられる遠心方向 へ鈎菌を率引する力は，近心ならびに煩側から負荷した 場合に発現した。

5) 最も多くの歯を鉤歯としたオリジナル・デザイン の場合の鈎歯変位量は，他のデザィンに比べて全般的に は最も小さく，義菌構成要素を漱次切除していくにした がって銁菌は小さい負荷に対しても容易に変位する傾向 が認められた。しいし，対側第 1 小曰菊の間接維持装置 をリンガルバーで連結したデザインの遠心への変位は才 リジナル・デザィンとほぼ同程度であった．

6 ) 対側の間接維持装置を切除した片側義歯では小さ な負荷に対しても極めて大きな遠心への変位傾向を示し た。

7 ) 義菌構成要素を溸次切除していった場合, 削除量 と鉤歯の総变位領域の增大との間には必ずしも相関関係 は認められなかった。

8 ）遊離端義歯の場合，床座面積を縮小すると義菌は 極めて不安定になり鈎歯の変位量も著しく増大した。

9 ) 荷重除去後は荷重時と異なった経路を通って復元 し，多くの場合鉤歯に回転的な挙動が観察された．

10）遊離端症例において鉤歯の保護に重点を置いた場 合には，義歯による誘導滑走をさけ可及的にディスクル ージョンを付与する必要性が示唆された。 
11）鉤菌の反対側の義蒾床部分に荷重を加えた場合に は極めて小さな鉤歯の変位量しか示さなかった．

12）鈎幽の同側後方に垂直的な脱離力が働いた場合 は，いずれのデザインの場合でも鉤㐘は複雑な挙動を示 したが，その変位量は間接維持装置を切除した片側デザ インの場合が最も大きかった。

謝 辞

稿を終わるにあたり，本研究に懇切なるで指導ならび にご校閲を賜った恩師豊田静夫教授に深甚の謝意を捧げ
ます．あわせて終始熱心なで指導と数多くので教示をい ただいた第 1 補緅学講座守川雅雄助教授ならびに歯科理 工学講座小園凱夫教授に心からお礼を申し上げます。ま た種々ので教示，で助言を賜った第 2 補緅学講座内田 康也教授に深く謝意を表わすと共に，コンピュータ㚮理 に際し多大のご協力をいただきました柬科理工学講座 柿川 宏, 田島清司, 両講師に深謝し数多くので助言を いただいた第 1 および第 2 補緅学講座各位に感謝致しま す.

\section{引用 文 献}

1) Henderson, D., McGivney, G.P. and Castleberry, D.J.: McCracken's removable partial prosthodontics. 7 th. ed., C.V. Mosby Co., St. Louis, 1985, 165.

2) 貫田静夫：遊離端義䨑に関す諸問題，特に義柬部の生理的形態について。日本歯科評論別冊：450一456, 1970 .

3 S Scott, C.H. : One piece cast removable appliances. J.A.D.A. $15: 1299-1304,1928$.

4 ) Pasadena Prosthetic Study Club: A study in partial denture construction. J.A.D.A. 20: $598-614,1933$.

5) Elliott, F.C.: A method that simplifies the design of partial dentures. J.A.D.A. 27:12631268,1940 .

6) Steffel, V.L. : Simplified clasp partial dentures designed for maximum function. J.A.D.A. $32: 1093-1101,1931$.

7) Schuyler, C.H. : Stress distribution as the prime requisite to the success of a partial denture. J.A.D.A. $20: 2148-2154,1933$.

8 ) McGee, D.V. : Stabilization of Partial dentures. J.A.D.A. $23: 545-553,1936$.

9) Stewart, K.L., Rudd, K.D. and Kuebker, W.A. : Clinical removable partial prosthodontics. C.V. Mosby CO., St. Louis, 1983, 94-112.

10) Boucher, L.J. and Renner, R.P. : Treatment of Partially edentulous patients. C.V. Mosby Co., St. Louis, $1982,1-127$.

11）尾花甚一・関根 弘・松尾悦郎・三谷春保：パーシャルデンチャーの臨床. 医歯薬出版, 東京, 1977, 147一 148 .

12) Girardot, R.L. : History and development of partial denture design. J.A.D.A. 28:13991413,1941 .

13) Neurohr, F.G. : Health conservation of the periodontal tissues by a method of functional partial denture design. J.A.D.A. 31:59-70, 1944 .

14) Kratochvil, F.J., and Vig, R.G. : Principles of removable partial dentures. U.C.L.A. Los Angeles, 1978, $1-104$.

15) Minden, F.V. : I deal stressbreaking for partial dentures. J.A.D.A. 30:657-669, 1943.

16) McGee, G.F.: The use of stressbreakers in tissue borne partial dentures. J.A.D.A.39: $387-392,1949$.

17) Jones, R.R. : The lower partial denture. J. Prosthet. Dent. $2: 219-229,1952$.

18) McLean, D.W. : The partial denture as a vehicle for function. J.A.D.A. 23:1271-1278, 
1936 .

19) Meyer, F.S. : Something new in cusps and sulci analysis, balanced and functional occlusion and stress breakers. J.A.D.A. $23: 1204-1212,1936$.

20) Jordan, L.G. : partial dentures. J.A.D.A. $29: 169-183,1942$.

21）Krol，A.J. (関根弘訳) : クロールパーシャルデンチャーデザィン，アイ・バー・クラスプ教本. 医歯楽 出版, 東京, $1976,16-95$.

22) Steffel, V.L. : Fundamental principle involved in partial denture design. J.A.D.A. 42:534544,1951 .

23) Steffel, V.L. : Clasp partial dentures. J.A.D.A. 66:803-811, 1963 .

24) Kratochvil, F.J. : Influence of occlusal rest position and clasp design on movement of abutment teeth. J. Prosthet. Dent. 13:114-124, 1963.

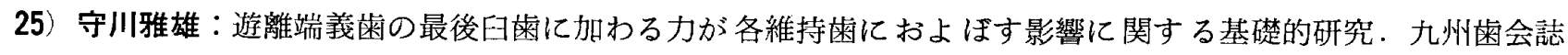
$27: 705-719,1974$.

26) Shohet, H. : Relative magnitudes of stress on abutment teeth with different retainers. $J$. Prosthet. Dent. $21: 267-282,1958$.

27) Taylor, D.T., Pflughoeft, F.A. and McGivney, G.P. : Effect of two clasping assemblies on arch integrity as modified by base adaptation. J. Prosthet. Dent. 47: 120-125, 1982.

28) Browning, J.D., Meadors, L.W. and Eick, J. D. : Movement of three removable partial denture clasp assemblies under occlusal loading. J. Prosthet. Dent. 55:69-74, 1986.

29) Ko, S.H., McDowell, G.C. and Kotowicz, W.E. : Photoelastic stress analysis of mandidular removable partial dentures with mesial and distal occlusal rests. J. Prosthet. Dent. 56: $454-460,1986$.

30) Clayton, J.A., and Jaslow, C. : A measurement of clasp forces on teeth. J. Prosthet. Dent. $25: 21-43,1971$.

31) Maxfield, J.B., Nicholls, J.B. and Smith, D.E. : The measurement of forces transmitted to abutment teeth of removable partial dentures. J. Prosthet. Dent. 41:134-142, 1979.

32) Tebrock, O.C., Rohen, R.M. and Fenster, G.B.Jr.: The effect of various clasping systems on the mobility of abutment teeth for distal-extension removable partial dentures. J. Prosthet. Dent. $41: 511-516,1979$.

33) Kratochvil, F.J. and Caputto, A.A.: Photoelastic analysis of pressure on teeth and bone supporting removable partial dentures. J. Prosthet. Dent. 32:52-61, 1972.

34) 榎本善保：遊離端義柬におけるクラスプの設計条件が支台歯の咬合圧負担状態に及ぼす影響に関する実験的 研究. 歯科学報 $72 ： 1072-1105,1972$.

35)大多和彦一：銁 (Clasp Rest) の畨牙に及ぼす影響について, 第 1 報, 主応力線について (Lines of principal stress (その 1 ). 秚科学報 $55: 329-334,1955$.

36)大多和彦一：鉤（Clasp Rest）の歯牙に及ぼす影響について (Lines of principal stress (完). 歯科学 報 $55: 395-402,1955$.

37) 大多和彦一：鉤（Clasp Rest）の㐘牙に及ぼす影響について, 第一報, 周辺応力の分布について. 歯科学 報 55:413-419，1955.

38) Morikawa, M., Sako, M., Kido, H., Toyoda, S. and Kozono, Y. : Analysis of abutment tooth movement utilizing mandibular kinesiograph (MKG), part 1 Characteristic aspects and correction of MKG records. Dent. Mater. J. $7: 188-196,1988$.

39) Morikawa, M., Masumi, S., Kido, H., Toyoda, S. and Kozono, Y. : Analysis of abutment tooth movement utilizing mandibular kinesiograph(MKG) Part 2 . Effects of clasp design 
in unilateral free-end denture. Dent. Mater. J. $8: 56-64,1989$.

40) Dowson, P.E. : Evaluation, diagnosis, and treatment of occlusal problems. C.V. Mosby Co., St. Louis, 1977, 80-100.

41) Frechette, A.K. : The influence of partial denture design on distribution of force to abutment teeth. J. Prosthet. Dent. $6: 195-212,1956$.

42) Kaires, A.K. : Effect of partial denture design on bilateral force distribution. J. Prosthet. Dent. $6: 373-385,1956$.

43) Kaires, A.K. : Effect of partial denture design on unilateral force distribution, J. Prosthet. Dent. $6: 526-534,1956$.

44) Henderson, D., and Seward, T.E. : Design and force distribution with removable partial dentures: Progress report. J. Prosthet. Dent. $17: 350-364,1967$.

45) Cecconi, B.T. and Asgar, K. : The effect of partial denture clasp design on abutment tooth movement. J. Prosthet. Dent. $25: 44-55,1971$.

46) Cecconi, B. T., Asgar, K. and Dootz, E. : Removable partial denture abutment tooth movement as affected by inclination of residual redges and type of loading. J. Proshtet. Dent. $25: 375-381,1971$.

47) Pendleton, E.C. : Influence of biologic factors in retention of artificial dentures. J.A.D.A. $23: 1233-1251,1936$. 